\title{
Perancangan Sistem Informasi Administrasi Jasa Keamanan Berbasis Web Studi Kasus: PT Pasopati Guardian Security Services
}

\author{
Obaja Marum Lumbanraja \\ Magister Sistem Informasi Bisnis, STMIK LIKMI \\ e-mail: obajalumbanraja@gmail.com
}

\begin{abstract}
Abstrak
Perusahaan membutuhkan teknologi informasi yang terintegrasi yang mampu menunjang kinerja perusahaan. Teknologi informasi terus berkembang pesat, mengisi tiap bidang dalam perusahaan dengan sistem. Salah satu bidang yang tidak luput oleh sentuhan teknologi informasi adalah bidang Administrasi. PT Pasopati Guardian Security Services membutuhkan sebuah sistem informasi administrasi untuk membantu meningkatkan kinerja perusahaan dan mengurangi kerugian bagi perusahaan. Adapun kegunaan yang diharapkan dari penelitian ini ada 4 yaitu 1) Meningkatkan kinerja karyawan dalam melakukan pekerjaannya. 2) Mengurangi kerugian yang tidak diperlukan karena tidak teraturnya data-data yang ada. 3) Mengurangi penggunaan kertas dalam pencatatan data anggota satuan pengaman, klien, pengeluaran keuangan dan pemasukan. 4) Menghemat waktu dalam pencarian data-data yang ada ketika diperlukan. Metodologi yang digunakan dalam penelitian ini adalah metode SDLC (System Development Life Cycle) yang terdiri dari lima tahap antara lain, (1) Analisa Kebutuhan, (2) Desain Sistem, (3) Coding, (4) Pengujian dan (5) Implementasi. Dari penelitian yang telah dilakukan, penulis menyimpulkan bahwa, (1) Sistem yang dibangun dapat meningkatkan kinerja karyawan dalam melakukan pekerjaannya, (2) Sistem yang dibangun dapat menyimpan dan menampilkan data pengeluaran keuangan dan pemasukan sesuai dengan data yang sebenarnya sehingga data lama dan baru dapat di analisa dengan baik, (3) Sistem yang dibangun dapat mengintegrasikan data antara anggota satuan pengaman dengan klien dengan benar sehingga dapat diketahui jumlah anggota yang ada di lokasi klien, dan (4) Sistem yang dibangun dapat membantu pengguna untuk membuat faktur sebelum tanggal jatuh tempo pembayaran oleh klien dan mengurangi kerugian yang dapat terjadi.
\end{abstract}

Kata Kunci: Sistem Informasi Administrasi, Berbasis Web, Jasa Keamanan;

\section{Web Based Security Services Administration Information System Design Case Study: PT Pasopati Guardian Security Services}

\begin{abstract}
Companies need integrated information technology capable of supporting the company's performance. Information Technology continues to grow rapidly, fills every field of the company with the system. One area or field that did not miss from Information Technology is field of Administration. PT Pasopati Guardian Security Services need an administration information system that help them to improve the company's performance and reduce the loss for the company. There were 4 goals of this research: 1) Improving the employee performance in doing his job. 2) Reducing unnecessary losses due to irregular available data. 3) Reducing the use of paper in the recording of data security force members, clients, financial expenses and income. 4) Saves time in searching existing data when needed. The methodology used in this research is SDLC (System Development Life Cycle) method which consists of five phases there are: (1) Requirement
\end{abstract}


Analysis, (2) System Design, (3) Coding, (4) Testing and (5) Implementation. From the research that has been done, the authors conclude that: (1) The system that was built is able to improve the performance of employees in doing his job, (2) The system that was built is able to store and display data of financial expenses and income in accordance with the actual data so the data of old and new can be analyzed properly, (3) The system that was built is able to integrate data between members of the security force and client so we can know the number of members in the client's location, and (4) The system that was built is able to help users to make the invoice before the due date of payment by the client and reduce losses that may occur.

Keywords: Information System Administration, Web Based, Security Services;

\section{Pendahuluan}

Perusahaan membutuhkan teknologi informasi yang terintegrasi yang mampu menunjang kinerja perusahaan. Teknologi informasi terus berkembang pesat, mengisi tiap bidang dalam perusahaan dengan sistem. Salah satu bidang yang tidak luput oleh sentuhan teknologi informasi adalah bidang Administrasi. Agar suatu perusahaan menjalankan perusahaannya dengan baik serta dapat meningkatkan kinerja perusahaan, dibutuhkan sistem administrasi yang baik, ini dikarenakan administrasi sangat dibutuhkan oleh perusahaan, di mana di dalamnya terdapat kegiatan pencatatan, klien dan personalia, keuangan dan kegiatan perkantoran umumnya. Sebuah sistem informasi administrasi dibutuhkan oleh semua perusahaan. Salah satunya adalah PT Pasopati Guardian Security Services. Perusahaan ini bergerak dibidang penyediaan jasa keamanan.

Kegiatan administrasi di PT Pasopati Guardian Security Services khususnya dalam pendataan klien, anggota, data pengeluaran keuangan dan data pemasukan masih memiliki kendala, di mana alur informasi yang ada terhambat dan susah untuk dilacak dikarenakan data-data tersebut tidak tersusun dan terstruktur dengan baik. Tidak jarang terjadi kesalahan informasi anggota maupun klien dikarenakan tidak sesuainya data yang lama dan yang baru yang mengakibatkan penunggakan pemasukan oleh klien kepada perusahaan maupun oleh perusahaan terhadap karyawan, tidak hanya itu kesalahan informasi tersebut juga menyebabkan kerugian yang tidak seharusnya terjadi bagi perusahaan maupun pihak yang terlibat. Berdasarkan permasalahan yang ada, penggunaan teknologi informasi akan sangat membantu kegiatan administrasi jasa keamanan pada PT Pasopati Guardian Security Services sehingga dapat meningkatkan kinerja perusahaan dan mengurangi kerugian bagi perusahaan.

Tujuan dari penelitian ini dilakukan adalah untuk menghasilkan sistem informasi administrasi jasa keamanan di PT Pasopati Guardian Security Services yang mampu meningkatkan kinerja perusahaan; dan menghasilkan sistem informasi yang mampu menyimpan dan menampilkan kembali data-data yang diperlukan user khususnya data anggota, klien, data pengeluaran keuangan dan pemasukan.

\section{Tinjauan Pustaka}

\section{Sistem Informasi}

Sistem dan informasi merupakan kata yang memiliki arti yang berbeda namun bila digabungkan akan menjadi sebuah alat yang sangat berguna seperti yang telah diungkapkan oleh para ahli. Berikut akan dijelaskan dasar teori sistem dan informasi. Sistem adalah sekumpulan elemen atau komponen yang berinteraksi untuk mencapai tujuan. komponen-komponen tersebut adalah: 1. Input (masukan), Input adalah aktivitas untuk mengumpulkan dan mendapatkan data mentah/raw data. 2. Processing (memproses), Processing berarti mengkonversi atau merubah data menjadi output yang berguna. 3. Output (keluaran), Output mencakup memproduksi informasi yang berguna, yang biasanya dalam bentuk dokumen-dokumen dan laporan-laporan. 4. Feedback (umpan balik), Feedback adalah informasi yang didapatkan dari sistem yang digunakan untuk melakukan perubahan terhadap aktivitas input atau proses [1]. Informasi terdiri dari 3 komponen pembentuk yaitu: 1. Data items (materi data), Mengacu pada 
deskripsi dasar dari hal, kejadian, kegiatan, dan transaksi yang dicatat, diklasifikasikan, dan disimpan namun tidak teratur untuk maksud/arti tertentu. Data items dapat berupa angka, huruf, suara, atau gambar. 2. Information (informasi), Informasi mengacu kepada data yang sudah teratur sehingga data tersebut mempunyai arti dan nilai bagi penerimanya. 3. Knowledge (pengetahuan), Terdiri dari data dan/atau informasi yang telah teratur dan di proses untuk menyampaikan pemahaman, pengalaman, akumulasi pembelajaran, dan keahlian sebagaimana informasi tersebut digunakan untuk permasalahanpermasalahan bisnis saat ini [2].

Berdasarkan ringkasan dari sistem dan informasi di atas didapatkan pengertian dari sistem informasi. Suatu sistem informasi adalah sekumpulan komponen yang saling terkait yang mengumpulkan, memanipulasi, menyimpan, dan menyebarkan data dan informasi dan menyediakan mekanisme umpan balik untuk memenuhi suatu tujuan.[1] Sistem informasi adalah kumpulan unsur yang saling terkait atau komponen yang mengumpulkan (input), memanipulasi (proses), menyimpan, dan menyebarkan (output) data dan informasi, dan memberikan reaksi (mekanisme umpan balik) korektif untuk memenuhi tujuan. Tujuan Sistem Informasi adalah untuk mendapatkan informasi yang tepat kepada orang yang tepat dengan jumlah yang tepat dan format yang tepat [2].

\section{Administrasi dan Jasa Keamanan}

Administrasi dalam suatu perusahaan diperlukan untuk memperlancar suatu kegiatan dalam sebuah organisasi, begitu juga keamanan diperlukan oleh setiap organisasi maupun individu. Berikut dijelaskan dasar teori dari administrasi dan jasa keamanan. Ada dua pengertian administrasi, yaitu administrasi dalam arti sempit dan administrasi dalam arti luas. [3]

1. Administrasi dalam arti sempit adalah kegiatan penyusunan dan pencatatan data dan informasi secara sistematis dengan tujuan untuk menyediakan keterangan serta memudahkan memperolehnya kembali secara keseluruhan dan dalam satu hubungan satu sama lain. Administrasi dalam arti sempit ini sebenarnya lebih tepat disebut dengan tata usaha.

2. Administrasi dalam arti luas adalah kegiatan kerja sama yang dilakukan sekelompok orang berdasarkan pembagian kerja sebagaimana ditentukan dalam struktur dengan menggunakan sumber daya untuk mencapai tujuan secara efektif dan efisien. Jadi, pengertian administrasi dalam arti luas memiliki unsur-unsur sekelompok orang, kerja sama, pembagian tugas secara terstruktur, kegiatan yang runtut dalam proses, tujuan yang akan dicapai, dan pemanfaatan berbagai sumber.

Intinya, administrasi melingkupi seluruh kegiatan, dari pengaturan hingga pengurusan sekelompok orang yang memiliki diferensiasi pekerjaan untuk mencapai suatu tujuan bersama. Sebagian besar literatur menggunakan istilah administrasi perkantoran dan manajemen perkantoran untuk menyebut administrasi. Hal ini dipertegas oleh pernyataan Perserikatan Bangsa Bangsa (1969), bahwa keduanya memiliki arti yang sama, walaupun istilah administrasi lebih banyak digunakan untuk hal-hal yang berhubungan dengan negara, sedangkan manajemen lebih banyak berkaitan dengan perusahaan. Ada 5 fungsi pendukung administrasi yaitu: 1. Fungsi Rutin, 2. Fungsi Teknis, 3. Fungsi Analisis, 4. Fungsi Interpersonal, 5. Fungsi Manajerial [3].

\section{Alat Bantu dalam Perancangan Sistem}

Dalam perancangan suatu sistem informasi dibutuhkan alat bantu untuk mempermudah perancangan sistem informasi tersebut. Berikut dijelaskan dasar-dasar teori dari alat bantu yang digunakan dalam perancangan sistem informasi administrasi ini. A. Data Flow Diagram (DFD) adalah model logika data atau proses yang dibuat untuk menggambarkan dari mana asal data dan ke mana tujuan data yang keluar dari sistem, di mana data disimpan, proses apa yang menghasilkan data tersebut dan interaksi antara data yang tersimpan dan proses yang dikenakan pada data tersebut". Langkah-langkah dalam Data Flow Diagram dibagi menjadi tiga tahap atau tingkatan, yaitu: 1. Diagram Konteks: Diagram dibuat untuk menggambarkan sumber serta tujuan data yang akan diproses atau dengan kata lain diagram konteks digunakan untuk menggambarkan sistem secara umum atau global keseluruhan sistem yang ada. 2. Diagram Nol: Diagram nol dibuat untuk menggambarkan tahapan proses yang ada di dalam diagram 
konteks, yang penjabarannya lebih terperinci. 3. Diagram Detail: Diagram detail dibuat untuk menggambarkan arus data secara lebih mendetail lagi dari tahapan proses yang ada di dalam diagram nol. Berikut adalah simbol-simbol yang digunakan dalam Data Flow Diagram [4]:

Tabel 1 Simbol-simbol Data Flow Diagram

\begin{tabular}{|l|c|l|}
\hline \multicolumn{1}{|c|}{ Nama Simbol } & \multicolumn{1}{|c|}{ Simbol } & \multicolumn{1}{c|}{ Keterangan } \\
\hline External Entity & \multicolumn{2}{|l|}{$\begin{array}{l}\text { Menggambarkan asal atau tujuan } \\
\text { data. }\end{array}$} \\
\hline Proses & $\longleftarrow$ & $\begin{array}{l}\text { Digunakan untuk memproses } \\
\text { pengolahan atau transformasi data. }\end{array}$ \\
\hline Data Flow & $\begin{array}{l}\text { Menggambarkan aliran data yang } \\
\text { berjalan. }\end{array}$ \\
\hline Data Store & $\square$ & $\begin{array}{l}\text { Menggambarkan aliran data yang } \\
\text { sudah disimpan atau diarsipkan }\end{array}$ \\
\hline
\end{tabular}

B. Entity Relationship Diagram (ERD): ERD mencerminkan database konseptual yang nantinya akan dilihat oleh pengguna/ user [5]. Model dasar ERD terdiri dari 3 kelas objek yaitu: 1. Entitas, Entitas adalah objek data yang pokok di mana semua informasi dikumpulkan; informasi tersebut biasanya ditunjukkan dengan orang, tempat, benda atau peristiwa. 2. Relasi, Relasi mewakili keadaan yang menghubungkan antara satu entitas dan entitas lainnya, dan oleh sebab itu relasi tidak memiliki keberadaan konseptual atau fisik selain dari entitas yang terhubung dengannya. 3. Attribut dan Keys, Atribut adalah karakteristik dari entitas yang menyediakan deskripsi yang rinci tentang entitas tersebut [6]. Terdapat 2 tipe atribut yaitu: a. Identifiers, Sebuah identifier (or key) digunakan untuk menentukan secara unik sebuah contoh dari suatu entitas. b. Descriptors, Sebuah descriptor (or nonkey attribute) digunakan untuk menunjukkan sebuah karakter yang tidak unik dari sebuah contoh entitas tertentu. Ada 3 notasi yang digunakan dalam ERD: - Notasi Chen : mendukung perancangan konseptual; - Notasi Crow's Foot: mendukung lebih banyak pendekatan yang berorientasi penerapan; - Notasi UML: dapat digunakan dalam perancangan konseptual maupun penerapan [5].

\section{Basis Data}

Manajemen data yang efisien biasanya membutuhkan penggunaan basis data komputer. Basis data adalah struktur komputer yang terintegrasi yang menyimpan dan membagi sekumpulan: struktur komputer yang terintegrasi yang menyimpan dan membagi sekumpulan: 1. End-user data yang adalah data mentah dari pengguna; 2. Metadata atau data tentang data, yang merupakan data pengguna yang saling terhubung dan dikelola oleh sistem. Terminologi sistem basis data merujuk kepada sebuah komponen organisasi yang menentukan dan mengatur pengumpulan, penyimpanan, manajemen dan penggunaan data dalam lingkungan basis data. Dari sudut pandang manajemen yang umum digunakan, sistem basis data terdiri dari lima bagian utama yaitu: 1 . Hardware; 2. Software; 3. Orang; 4. Prosedur; \& 5. Data [5]. MySQL adalah database relasional dengan fitur lengkap namun gratis. MySQL mulai dikembangkan pada tahun 1990an untuk memenuhi kebutuhan akan perkembangan komputer dalam mengatur informasi dengan pintar. MySQL mendukung beberapa mesin basis data yang berbeda. Mesin basis data menentukan bagaimana MySQL menangani penyimpanan aktual dan query data. Oleh karena itu, setiap mesin penyimpanan mempunyai kemampuan dan kekuatannya masing-masing. Seiring waktu, mesin basis data yang ada menjadi lebih baik dan cepat. Versi MySQL yang ada saat ini adalah 5.0x. MySQL 5.0 memberikan performa yang dapat dibandingkan dengan basis data enterprise mahal lainnya seperti, Oracle, Informix, DB2 (IBM) dan SQL Server (Microsoft) [7]. XAMPP adalah Apache open source yang memiliki MySQL, PHP dan Perl, yang sangat mudah di install dan digunakan. XAMPP dapat menyediakan sebuah lingkungan pengembangan web secara lokal yang dapat dengan mudah digunakan tanpa perlu di lakukan percobaan di server public atau tempat penyimpanan (hosting) [8]. 


\section{Bahasa Pemrograman}

Dalam membuat sistem informasi dibutuhkan bahasa yang dapat berinteraksi dengan komputer, bahasa tersebut disebut code. Code berisi perintah-perintah yang digunakan untuk membangun sistem informasi. Untuk mengolah code dibutuhkan bahasa pemrograman yang memudahkan dalam pengerjaannya. Berikut dijelaskan dasar teori dari PHP, HTML, dan CSS. 1. PHP (Hypertext Preprocessor) adalah bahasa pemrograman yang dirancang untuk menghasilkan halaman web yang interaktif pada komputer dengan bantuan web server. Kode PHP berjalan di antara halaman yang diminta dan web server, di mana PHP mengubah dan menambah output yang dimiliki oleh kode HTML dasar. PHP membuat mudah para pengembang web dikarenakan semua kode yang dibutuhkan sudah tersedia dalam PHP framework [7]. 2. HTML (HyperText Markup Language): HTML adalah salah satu bahasa pemrograman yang digunakan untuk membangun sebuah halaman web. Kode HTML dibentuk oleh kumpulan karakter yang berada di antara kurung siku $(\{\})$, yang disebut elemen HTML. Elemen biasanya terdiri dari 2 tag: sebuah tag pembuka dan sebuah tag penutup (tag penutup memiliki tambahan tanda garis miring (/) di dalamnya). Setiap elemen HTML memberitahu browser tentang informasi yang berada di antara tag pembuka dan tag penutup. Tag bertindak seperti kontainer. Tag memberikan informasi apa yang ada di antara tag pembuka dan tag penutup. Atribut memberikan tambahan informasi mengenai isi yang ada pada elemen. Atribut berada di antara tag pembuka dari elemen dan terdiri dari dua bagian: sebuah nama dan nilai, yang dipisahkan dengan tanda sama dengan (=) [9]. 3. CSS (Cascading Style Sheets): CSS adalah bahasa pemrograman yang digunakan untuk mendesain isi yang ada di dalam halaman web. CSS bekerja dengan memungkinkan seorang pengembang mengasosiasikan aturan-aturan dengan elemen-elemen yang akan muncul pada halaman web. Ini memungkinkan pengembang mengatur tampilan dengan unsur-unsur yang dibutuhkan. Aturan pada CSS terdiri atas dua bagian yaitu: a. Selector: menunjukkan elemen apa yang akan di rubah; b. Declaration: menentukan bagaimana elemen tersebut akan diatur sesuai dengan selector yang dimaksud[10].

\section{Metode Penelitian}

\section{Profil PT Pasopati Guardian Security Services}

Keamanan adalah aspek penting bagi seorang individu ataupun perusahaan. PT Pasopati Guardian Security Services adalah perusahaan yang bergerak dibidang pengadaan jasa keamanan. Awal mula terbentuknya perusahaan ini didasari atas kesadaran pendiri akan pentingnya keamanan bagi tiap individu maupun perusahaan. PT Pasopati Guardian Security Services berdiri pada tanggal 1 Mei 2008 dan berganti kepengurusan pada tanggal 17 Februari 2015 yang mengakibatkan terjadinya perubahan cukup besar dalam manajemen kepengurusan perusahaan. PT Pasopati Guardian Security Service mulai menerapkan teknologi dalam meningkatkan pelayanan kepada klien sejak tahun 2015, di mana terdapat sistem yang diintegrasikan dengan cctv yang hasilnya dipantau oleh petugas melalui monitor pengawas di markas besar dan juga melalui android/smartphone klien ataupun admin dari PT Pasopati Guardian Security Services. Saat ini permintaan akan tenaga satuan pengaman melalui PT Pasopati Guardian Security Services meningkat tiap bulannya, klien pengguna jasa keamanan tidak hanya datang dari perusahaan namun juga dari perseorangan atau individu.

\section{Analisis Kebutuhan Sistem}

Dalam perancangan sistem administrasi ini terdapat beberapa fungsi yang bisa dilakukan, di antaranya:

1. Fungsi mengolah data anggota: a. Membuat data anggota baru, Fungsi ini digunakan untuk membuat data anggota satuan pengaman baru dengan keterangan nama, alamat, status kontrak, waktu kontrak, nomor surat mutasi dan keterangan lainnya. b. Menampilkan data anggota, Fungsi ini berguna untuk menampilkan data anggota satuan pengaman yang sudah dibuat sebelumnya dengan tambahan fitur mengubah, menghapus dan detail anggota tersebut. 
2. Fungsi mengolah data klien: a. Membuat data klien baru, Fungsi ini digunakan untuk membuat data klien baru dengan keterangan nama klien, alamat, produk yang dipilih klien, nomor kontrak, tanggal mulai dan berakhir kontrak, nilai kontrak dan keterangan lainnya. b. Menampilkan data klien, Fungsi ini berguna untuk menampilkan data klien yang sudah dibuat sebelumnya dengan tambahan fitur mengubah dan menghapus data yang klien yang ada. c. Menampilkan data personil di area klien, Fungsi ini berguna untuk melihat data personil satuan pengaman yang bertugas di area klien.

3. Fungsi mengolah data pengeluaran keuangan: a. Membuat laporan data pengeluaran keuangan baru, Fungsi ini digunakan untuk membuat data pengeluaran keuangan yang baru dengan keterangan tanggal pengeluaran, nomor nota, keterangan pengeluaran, diketahui oleh dan keterangan lainnya. $b$. Menampilkan data laporan pengeluaran keuangan, Fungsi ini berguna untuk menampilkan data laporan pengeluaran keuangan yang sudah dibuat sebelumnya dengan tambahan fitur mengubah dan menghapus data pengeluaran keuangan yang ada.

4. Fungsi mengolah data pemasukan keuangan: a. Membuat laporan data pemasukan keuangan baru, Fungsi ini digunakan untuk membuat data pemasukan keuangan yang baru dengan keterangan tanggal transfer, ke rekening mana, nomor invoice, diketahui oleh dan keterangan lainnya. b. Menampilkan data laporan pemasukan keuangan, Fungsi ini berguna untuk menampilkan data laporan pemasukan keuangan yang sudah dibuat sebelumnya dengan tambahan fitur mengubah dan menghapus data pemasukan keuangan yang ada.

\section{Analisis Pengguna Sistem}

Bagian ini akan menjelaskan siapa saja yang akan menggunakan sistem informasi administrasi ini, yang di antaranya: 1. Direktur Utama dan Direktur Keuangan \& SDM: a. Membuat dan Menghapus Admin; b. Mengolah data anggota; c. Mengolah data klien; d. Mengolah data pengeluaran dan pemasukan; 2. Staf Administrasi: a. Mengolah data anggota, b. Mengolah data klien, c. Mengolah data pengeluaran dan pemasukan

Metode perancangan yang digunakan adalah metodologi yang umum digunakan dalam siklus pengembangan sistem (System Development Life Cycle) yang dibagi dalam beberapa tahapan antara lain:

\section{Analisa Kebutuhan}

Tahap pertama yang dilakukan adalah analisa kebutuhan yang diperlukan untuk dimasukkan ke dalam sistem. Tahap ini akan banyak melibatkan user, di mana merekalah yang nantinya akan menggunakan sistem yang akan dibangun, oleh karena itu pada tahap ini dibutuhkan banyak masukan mengenai fitur atau menu yang dimiliki di dalam sistem agar sistem yang dibangun sesuai dengan kepentingan stakeholders.

\section{Desain Sistem}

Setelah dilakukan analisa kebutuhan, tahap selanjutnya adalah mendesain sistem dalam bentuk rancangan diagram konteks, rancangan data flow diagram, dan rancangan basis data sistem.

\section{Coding}

Tahap ini adalah tahap di mana proses logika berpikir diterjemahkan ke dalam kata-kata yang membentuk code dalam bahasa pemrograman tertentu yang dimengerti oleh komputer, di mana code tersebut dijalankan dan menghasilkan sebuah sistem yang dibangun sesuai dengan isi dari perintah code tersebut.

\section{Pengujian}

Setelah sistem dibangun, dilakukanlah pengujian terhadap sistem apakah sudah sesuai dengan kriteria yang dimaksud dan sesuai dengan kebutuhan user.

\section{Implementasi}


Tahapan terakhir adalah melakukan implementasi sistem informasi yang dibangun sesuai dengan prosedur dan aturan yang berlaku dalam organisasi.

\section{Diagram Konteks}

Pada Gambar 1, diagram konteks menjelaskan alur dari setiap data yang disimpan ke dalam database dan ditampilkan kembali melalui sistem dalam bentuk informasi dari data yang dimaksud. Dimulai dari staf administrasi menerima data keuangan, data klien dan data anggota dari staf keuangan maupun kepala operasional (mereka yang berhubungan dengan anggota satuan pengaman) yang akan diolah dan dimasukkan ke dalam sistem. Selanjutnya staf administrasi akan mengolah data tersebut dan memasukkannya ke dalam sistem sesuai dengan prosedur yang berlaku. Terakhir data yang telah dimasukkan akan menjadi informasi yang berguna bagi staf administrasi, direktur maupun perusahaan ke depannya.

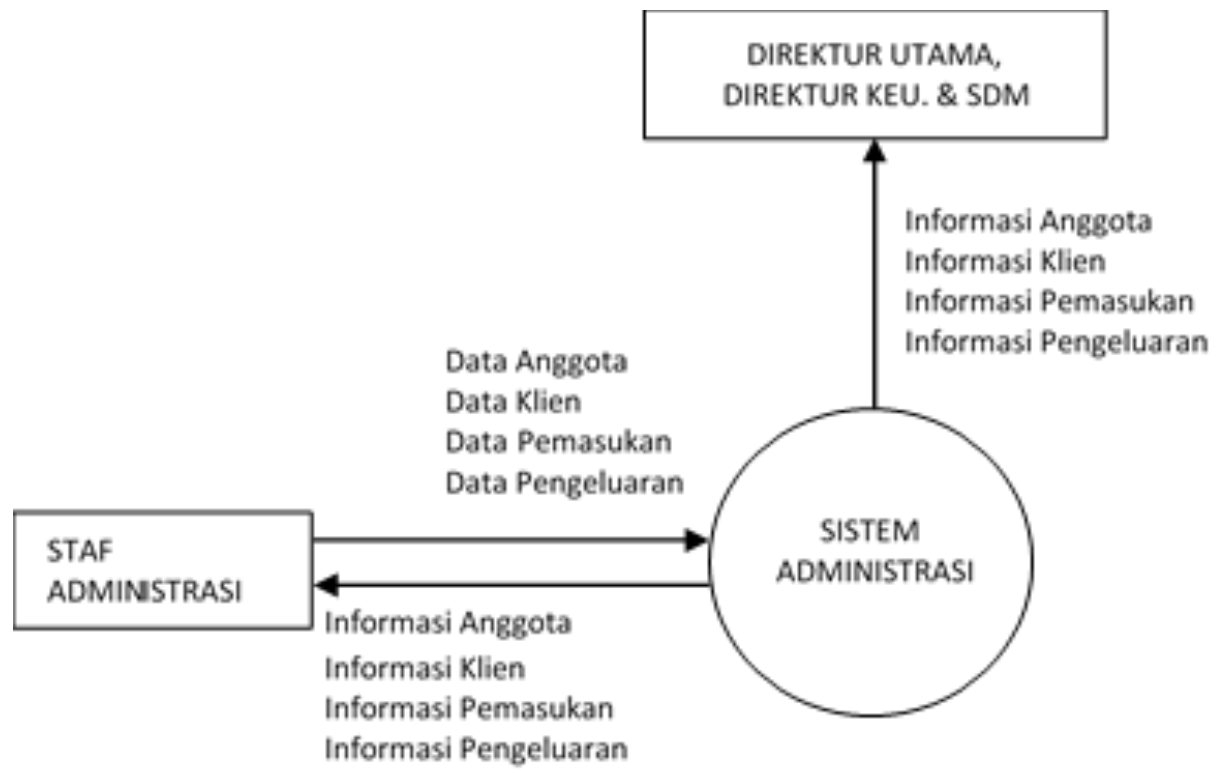

Gambar 1 Diagram Konteks Sistem Informasi Administrasi

Data Flow Diagram (DFD), Setelah sistem di analisa menggunakan diagram konteks, maka untuk memahami sistem secara logika, terstruktur dan jelas maka penulis menggambar arus dari data sistem seperti pada gambar 2 di bawah ini. 


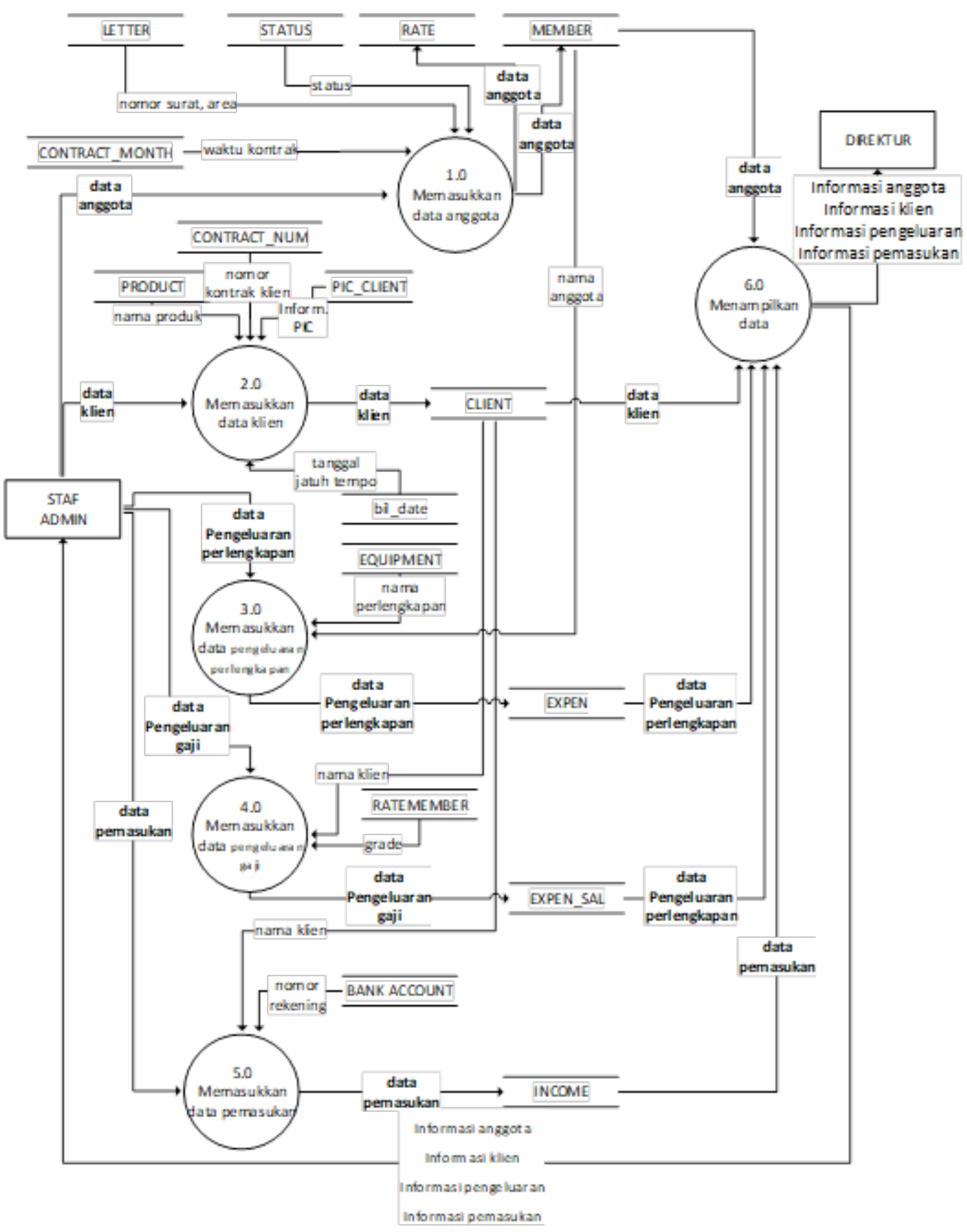

Gambar 2 Data Flow Diagram Level 0

Pada gambar 3 Chen ERD Notation menggambarkan setiap entitas yang saling berhubungan di mana keseluruhan Entity memiliki Relationship yang sama yaitu Melibatkan, ini dikarenakan di saat staf administrasi memasukkan data yang ada, setiap entitas yang ada terlibat satu sama lain, seperti saat staf administrasi akan memasukkan data Anggota (Member) maka entitas Letter, Status, Contract_Month akan saling terlibat, hal ini juga terjadi saat user akan memasukkan data Klien (Client) maka entitas Contract_Num, Bil_Date, Product akan terlibat. 


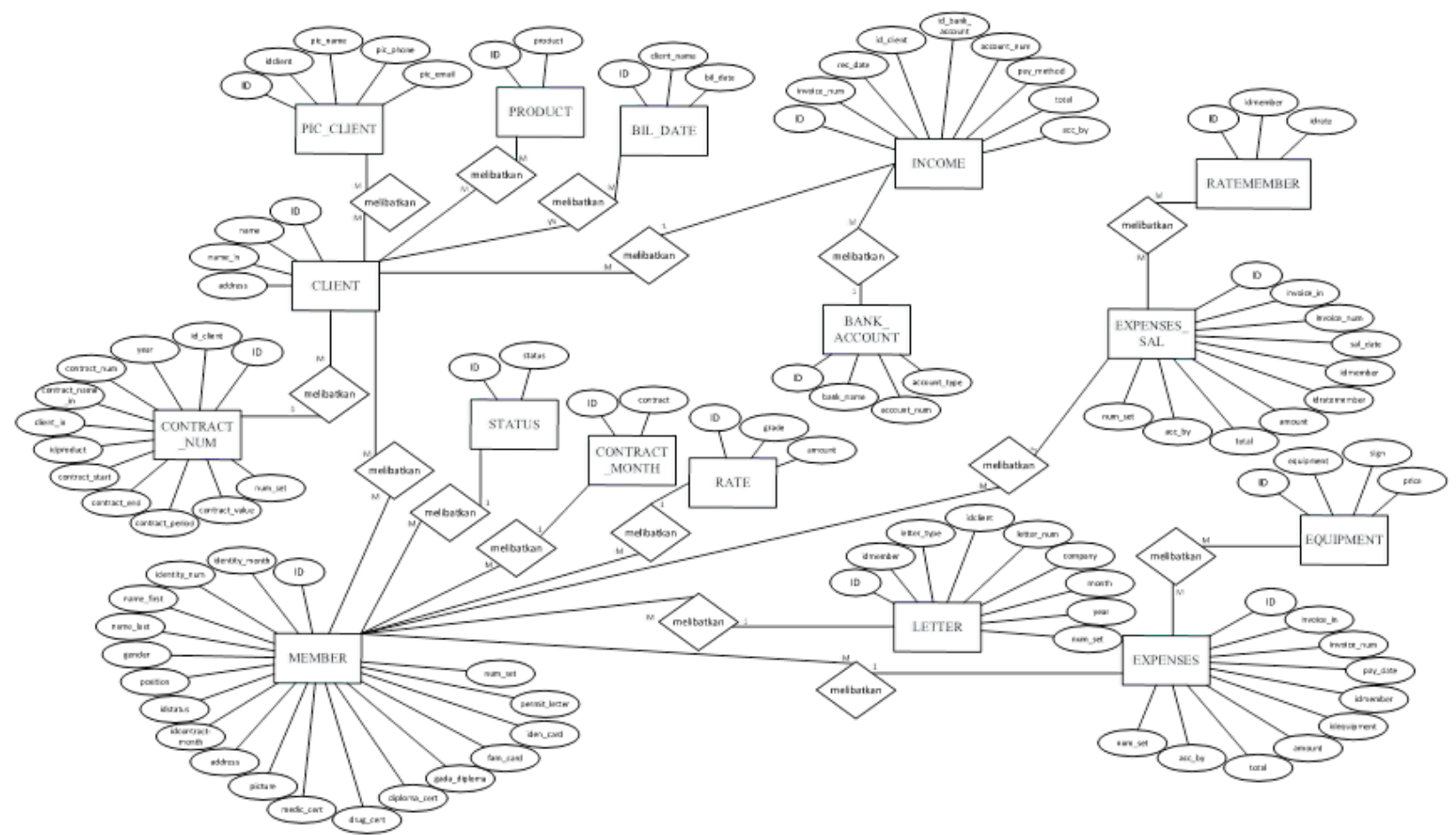

Gambar 3 Chen ERD Notation

Pada gambar 4 Crow's Foot Notation menggambarkan relasi antar tabel dalam sistem, di mana seperti pada diagram Chen, setiap tabel memiliki hubungan 1 to 1 , ini dikarenakan pada setiap tabel memiliki maksimal 1 attribute/field yang berasal dari tabel lainnya.

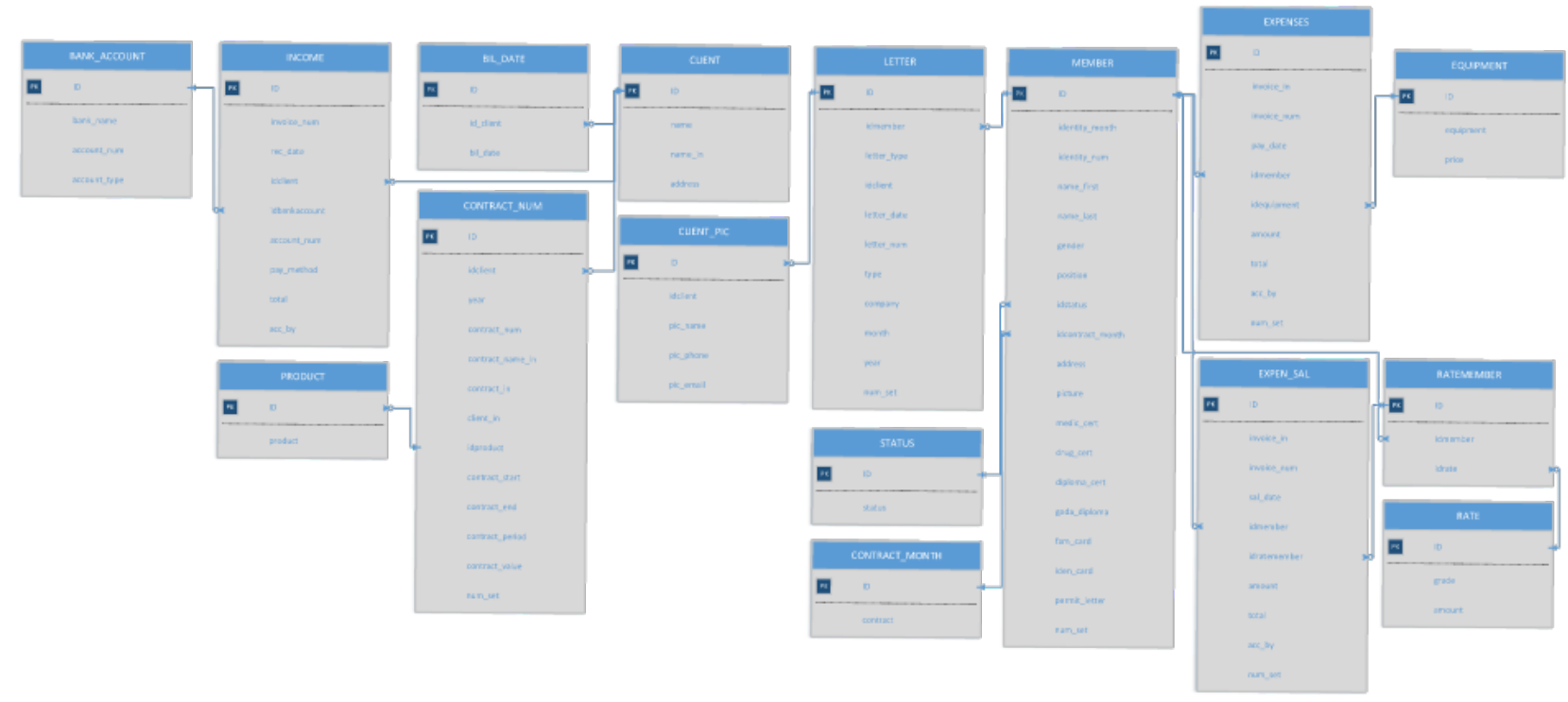

Gambar 4 Crow's Foot ERD Notation 


\section{Perancangan Antarmuka}

Perancangan antarmuka menjelaskan gambaran perancangan tampilan pada setiap halaman yang akan digunakan pada sistem informasi ini.
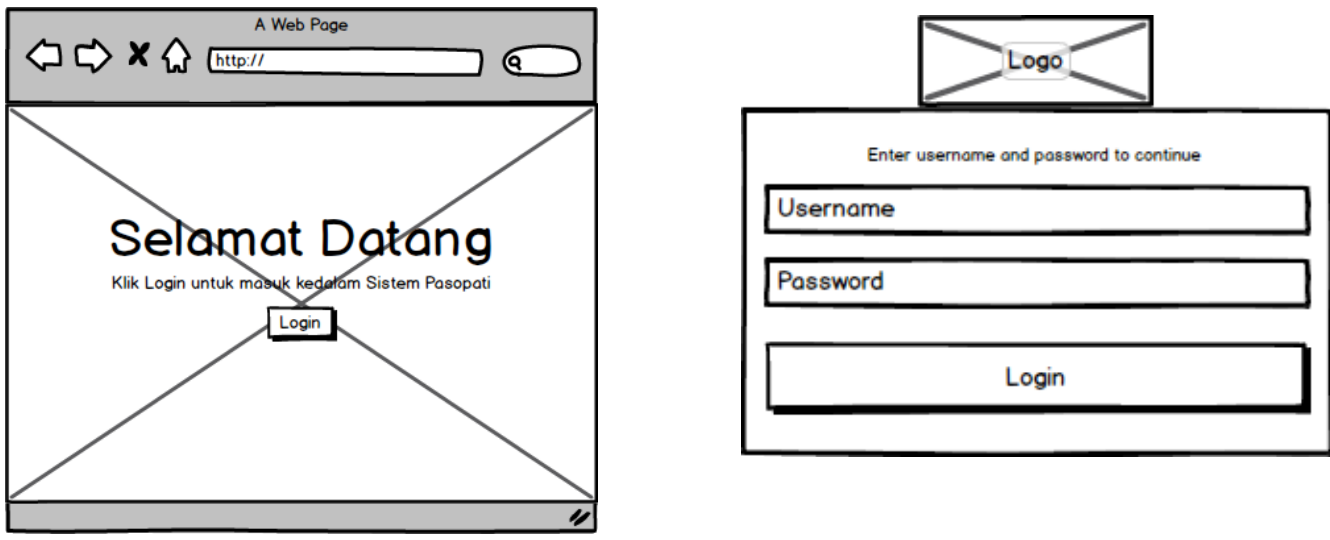

Gambar 5 Landing Page \& Login Page

Gambar 5 Landing Page, merupakan tampilan yang merupakan halaman awal yang berisi kata sambutan dari sistem informasi administrasi. Pada halaman ini user akan melihat tampilan selamat datang serta tombol untuk masuk ke dalam halaman login sistem yang bertuliskan "login". Login Page, merupakan halaman untuk masuk ke dalam sistem. Hanya mereka yang mempunyai hak akses saja yang dapat masuk ke dalam sistem.
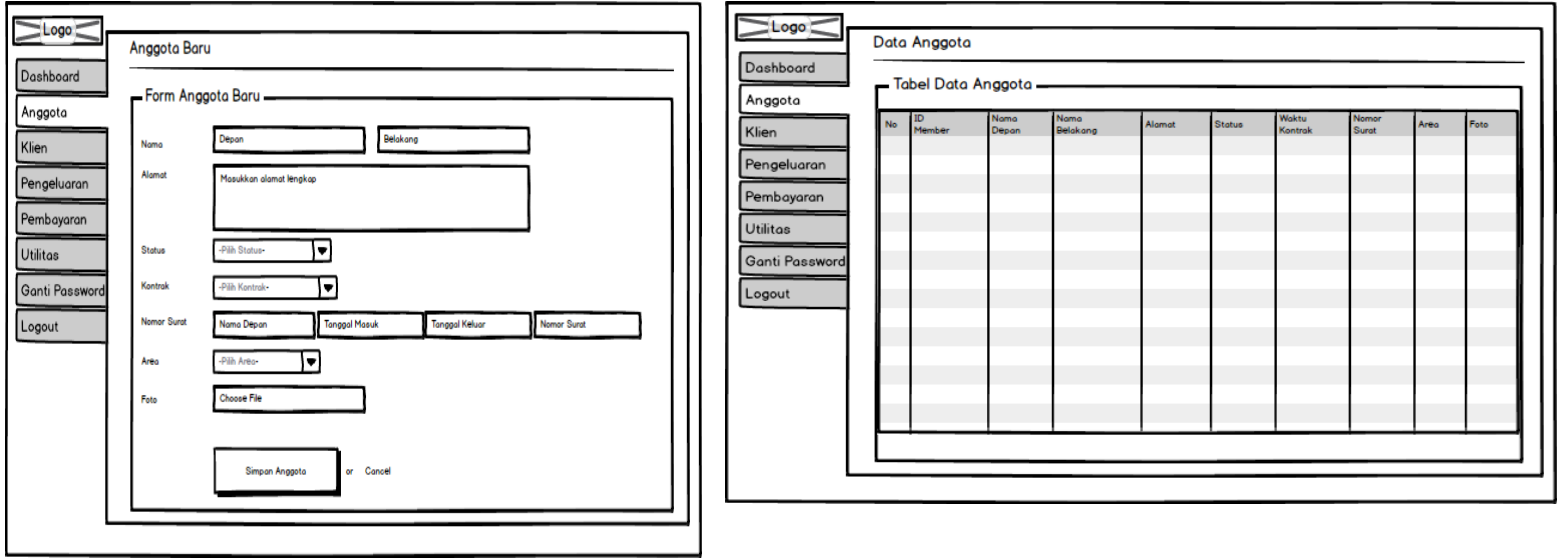

Gambar 6 Halaman Anggota Baru \& Halaman Data Anggota

Gambar 6 Halaman Anggota Baru, digunakan untuk membuat anggota baru dengan keterangan seperti gambar. Pada halaman ini userakan dihadapkan pada submenu anggota, yakni anggota baru, pada halaman ini userakan memasukkan data anggota seperti pada gambar. Halaman Data Anggota, digunakan untuk melihat data anggota yang sudah dibuat sebelumnya dengan keterangan seperti gambar. 

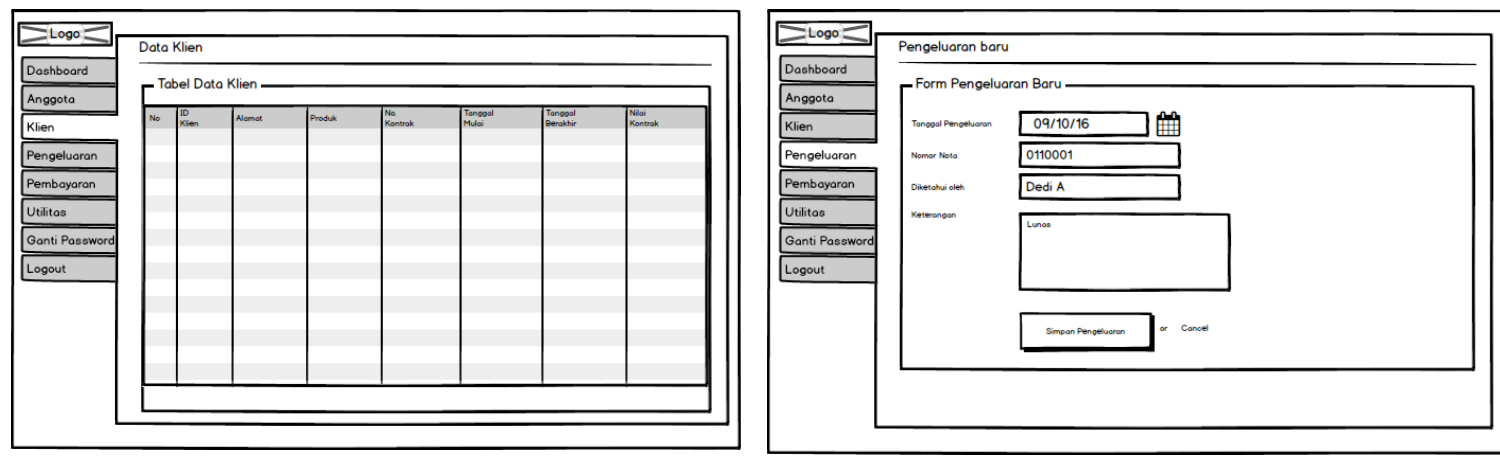

Gambar 7 Halaman Data Klien \& Halaman Pengeluaran Keuangan Baru

Gambar 7 Halaman Data Klien, digunakan untuk melihat data anggota yang sudah dibuat sebelumnya dengan keterangan seperti gambar. Halaman Pengeluaran Keuangan Baru, digunakan untuk membuat pengeluaran keuangan baru dengan keterangan seperti gambar.
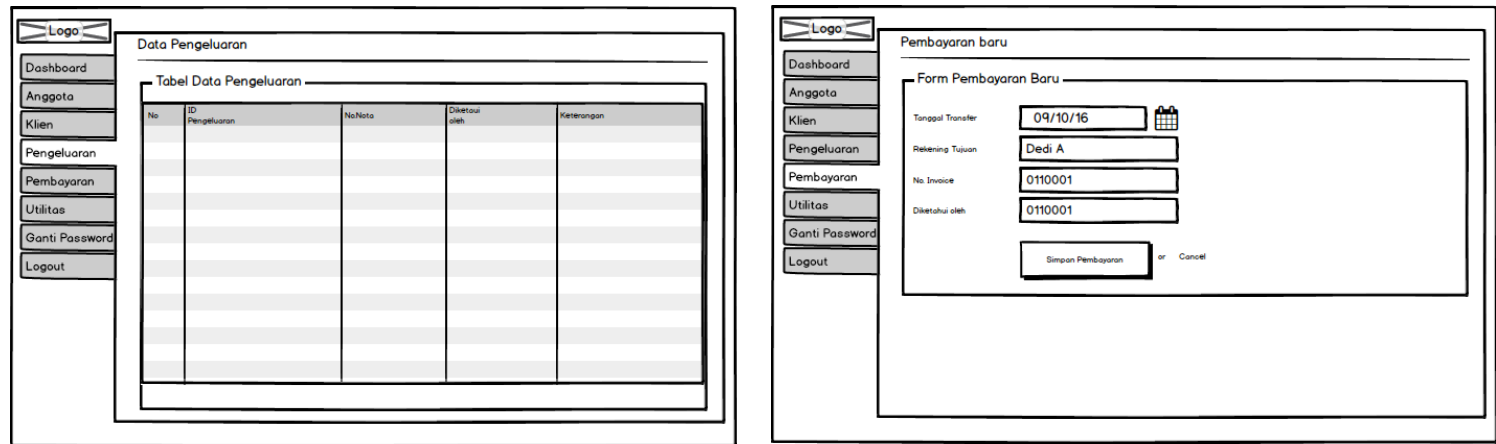

Gambar 8 Halaman Data Pengeluaran Keuangan \& Halaman Pemasukan Keuangan Baru

Gambar 8 Halaman Data Pengeluaran Keuangan, digunakan untuk melihat data pengeluaran keuangan yang sudah dibuat sebelumnya. Halaman Pemasukan Keuangan Baru, digunakan untuk membuat pemasukan keuangan baru dengan keterangan seperti gambar.
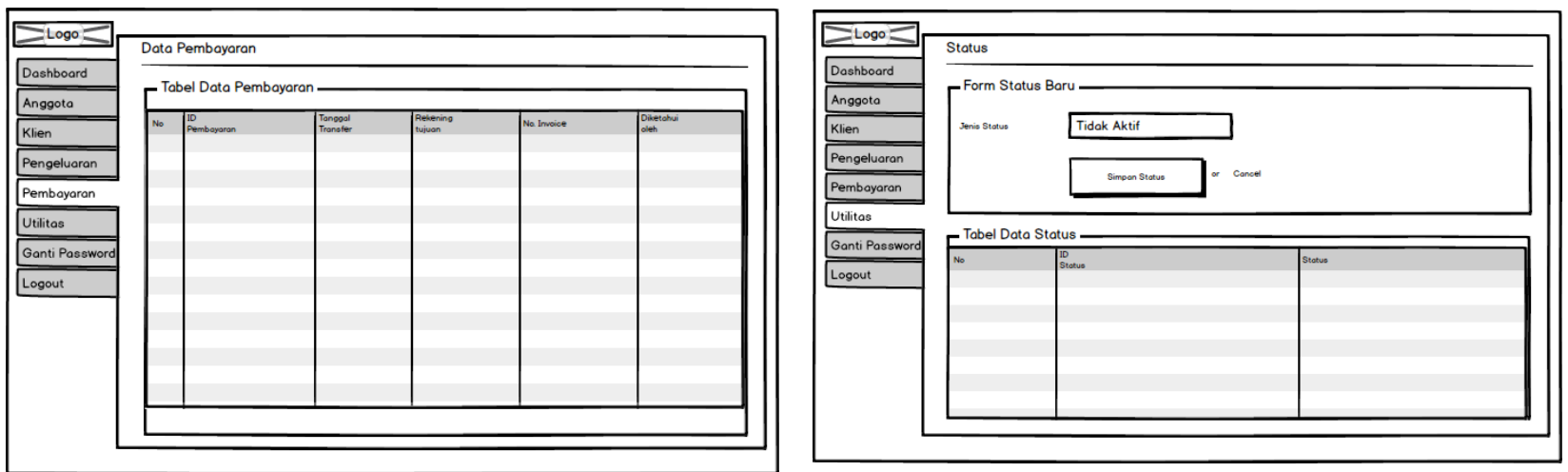

Gambar 9 Halaman Data Pemasukan Keuangan \& Halaman Status

Gambar 9 Halaman Data Pemasukan Keuangan, digunakan untuk melihat data pemasukan keuangan yang sudah dibuat sebelumnya. Halaman Status, digunakan untuk membuat status baru dan melihat data yang sudah dibuat dengan keterangan seperti gambar. 

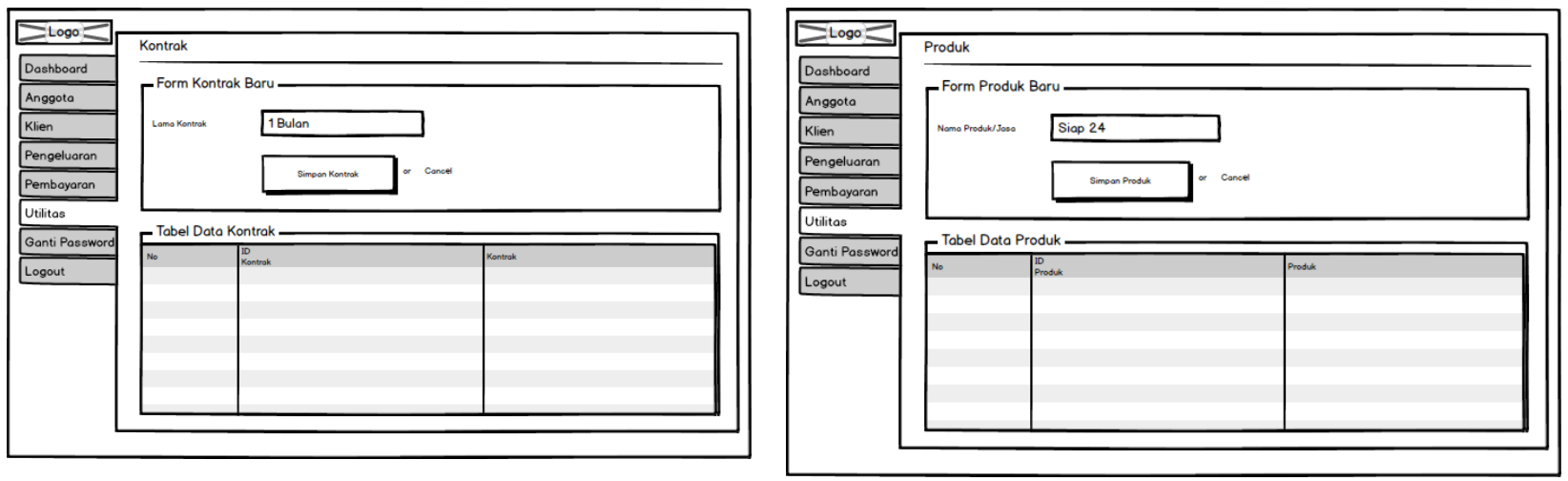

Gambar 10 Halaman Kontrak \& Halaman Produk

Gambar 10 Halaman Kontrak, digunakan untuk membuat kontrak baru dan melihat data yang sudah dibuat dengan keterangan seperti gambar. Halaman Produk, digunakan untuk membuat produk baru dan melihat data yang sudah dibuat dengan keterangan seperti gambar.

\section{Hasil Perancangan}

Tampilan terdiri dari tampilan antar muka admin. Tampilan admin memiliki tampilan awal halaman dashboard serta menu anggota, klien, pengeluaran, pemasukan, surat, kontrak klien, utilitas dan ganti password. Gambar 11 Halaman Landing Page, Untuk dapat mengakses sistem administrasi ini, pegawai dapat mengetikkan alamat localhost/syspasopati pada browser. Userakan diarahkan ke halaman awal atau landing page. Berikut adalah tampilan awal saat user mengetik alamat localhost/syspasopati. Sesudah halaman tampil, user akan diarahkan pada tombol login untuk masuk ke dalam sistem.

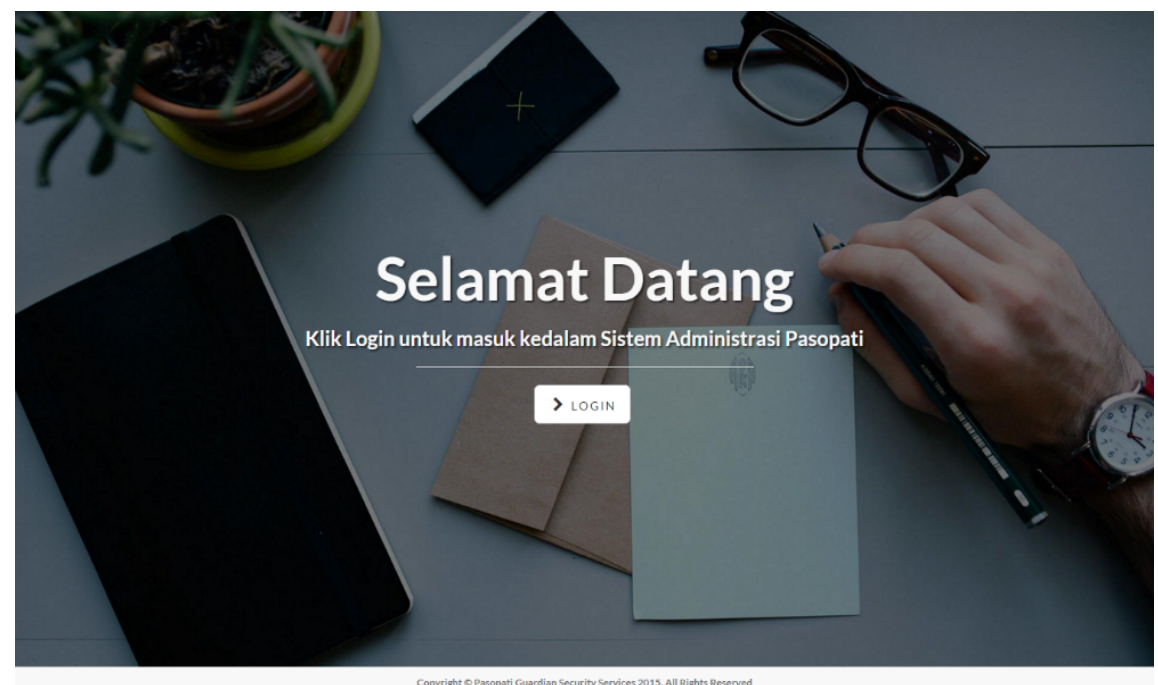

Gambar 11 Halaman Landing Page

Halaman login adalah batasan bagi mereka yang tidak mempunyai hak akses untuk mengakses sistem. Untuk dapat mengakses sistem user harus mempunyai dan mengetahui username serta password. Gambar 12 merupakan tampilan halaman login tersebut. 


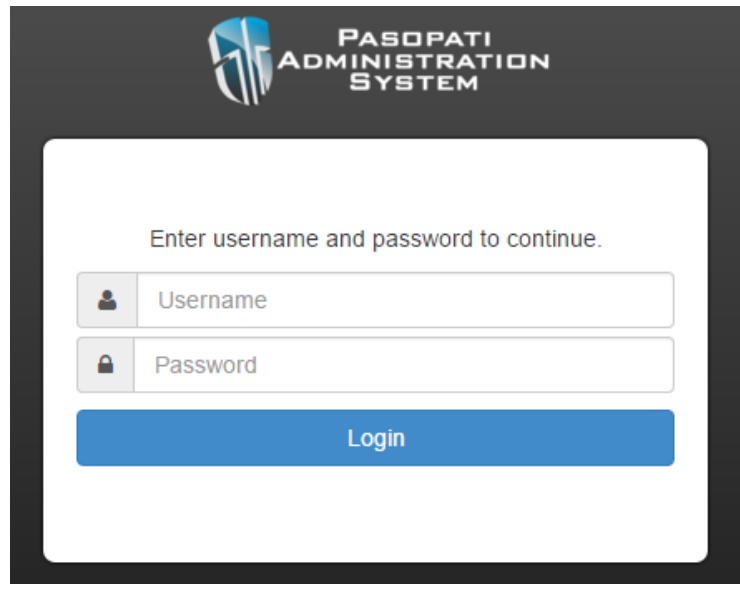

Gambar 12 Halaman Login Page

Halaman Dashboard. Bila user memiliki hak akses untuk mengakses sistem, maka user akan melihat tampilan awal sistem yaitu dashboard. dashboard menyediakan informasi bagi user, khususnya pemberitahuan pembuatan faktur yang akan tampil 10 hari sebelum tanggal jatuh tempo pembayaran oleh klien, dihitung dari 1 bulan setelah tanggal kontrak dimulai dikurang 10 hari. Sebagai contoh bila tanggal kontrak dimulai tanggal 14-11-2015 maka sistem akan menambahkan 1 bulan menjadi tanggal 14-12-2015 dikurang 10 hari dari tanggal tersebut menjadi tanggal 04-12-2015 di mana notifikasi akan muncul di halaman dashboard. Gambar 13 menggambarkan tampilan halaman beserta pemberitahuannya

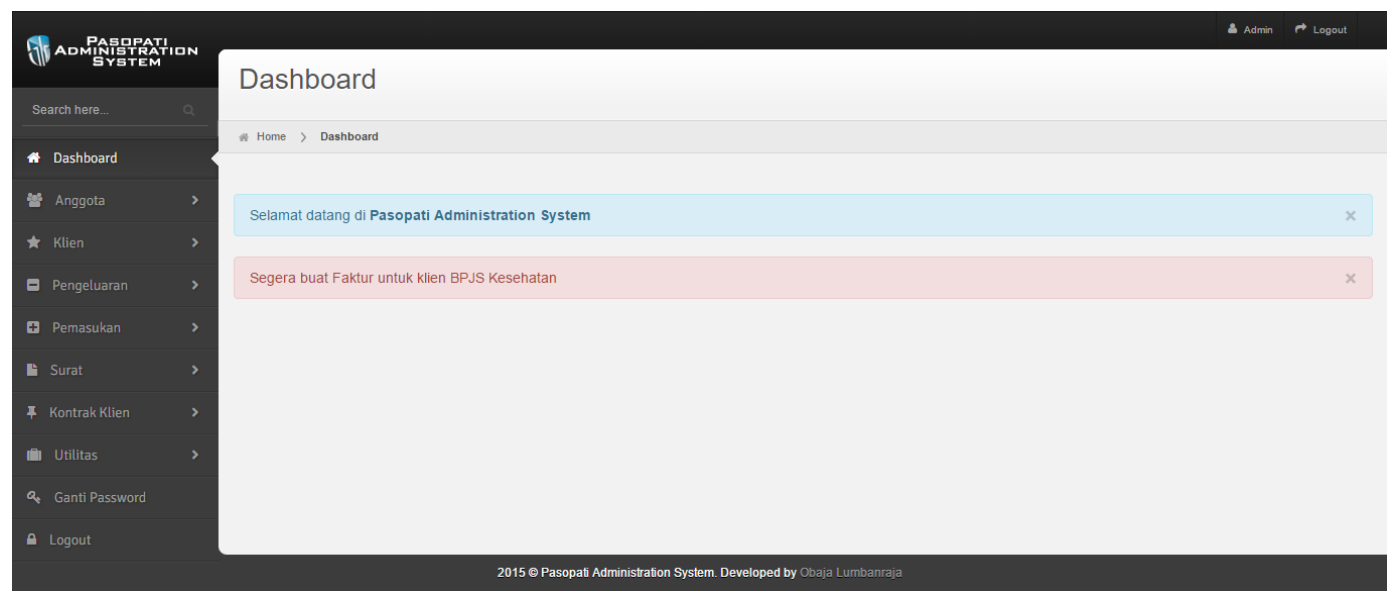

Gambar 13 Halaman Dashboard

Menu anggota adalah tempat user untuk memasukkan data dan melihat data anggota yang sudah dimasukkan sebelumnya dalam bentuk informasi anggota yang terdiri dari sub menu anggota baru, data anggota, rate anggota baru dan data rate anggota yang ditunjukkan pada Gambar 14, Gambar 15, Gambar 16 dan Gambar 17. Sebelum user memasukkan data anggota maka user harus membuat nomor surat di menu surat terlebih dahulu bila tidak ingin data nomor surat ditulis "surat belum dibuat", selain itu user juga harus membuat data klien terlebih dahulu agar pilihan untuk area di saat ingin menambahkan anggota baru dapat ditampilkan. 


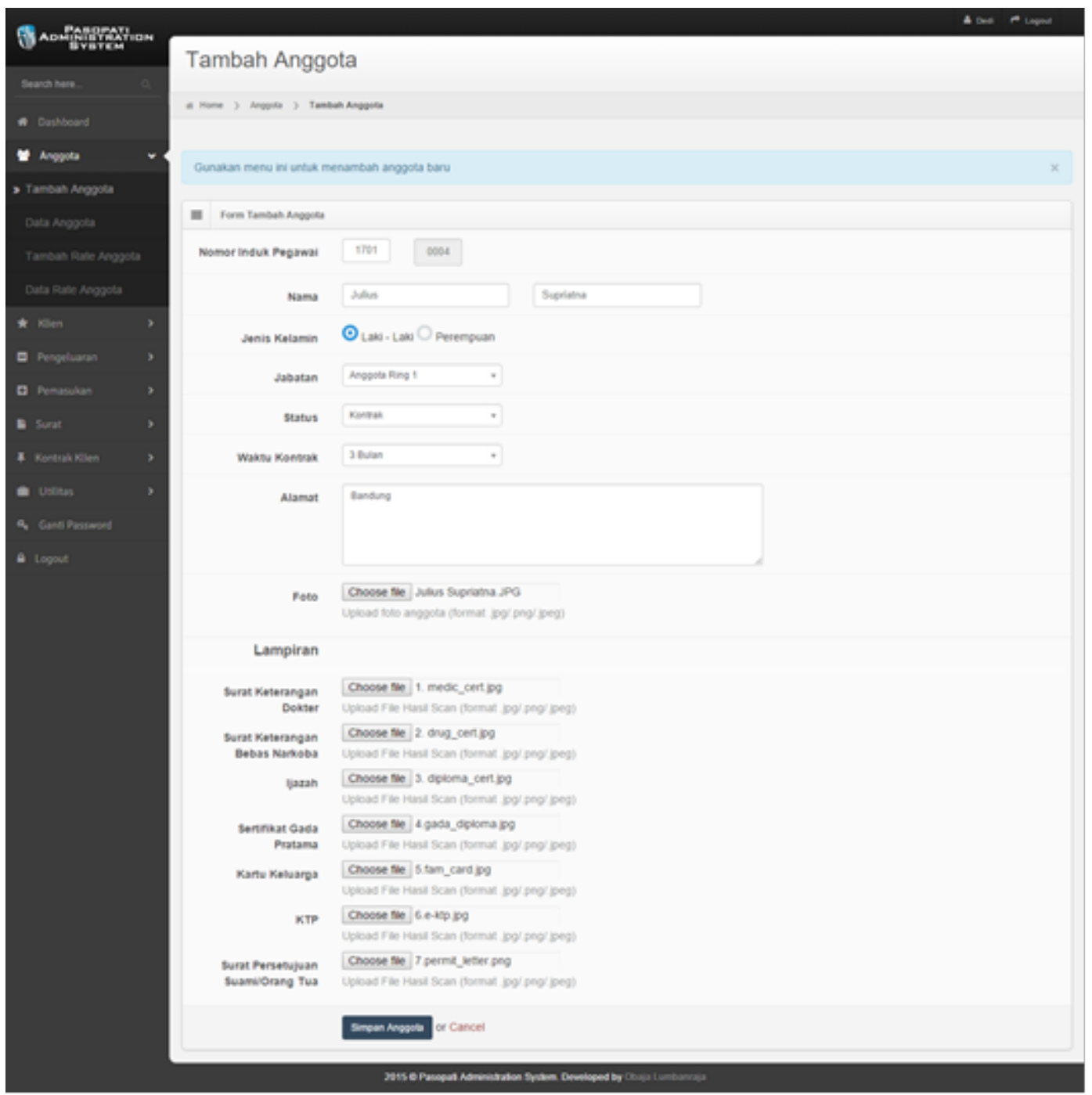

Gambar 14 Tampilan Sub Menu Tambah Anggota

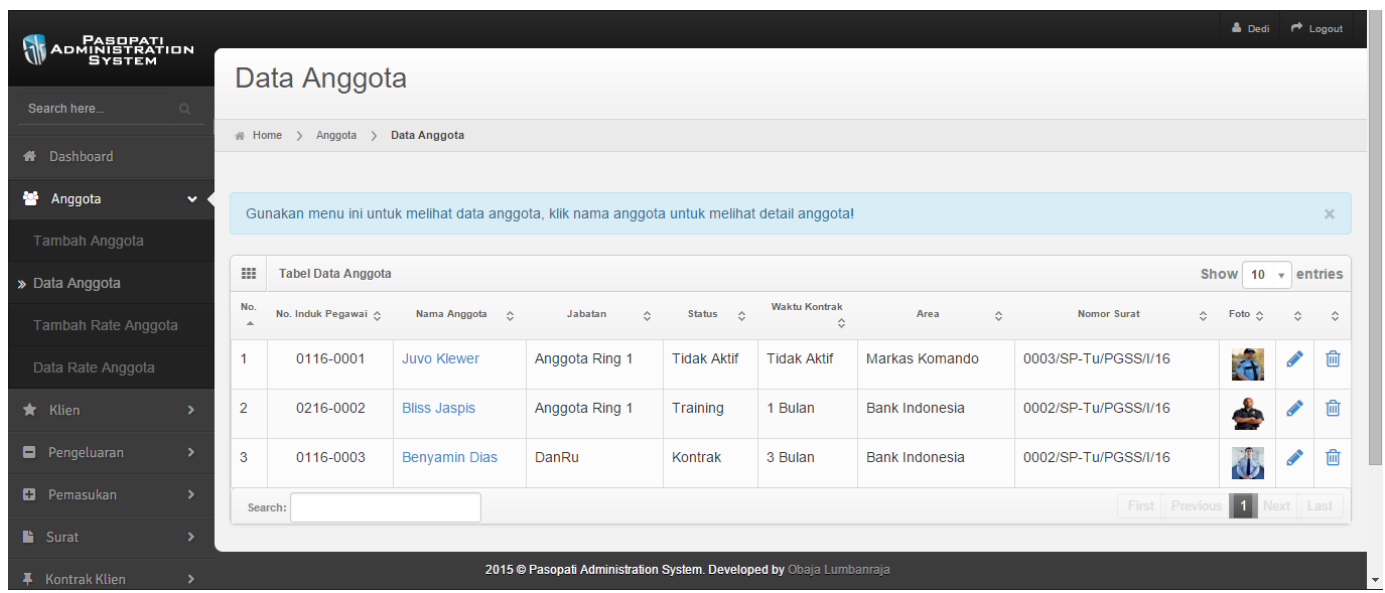

Gambar 15 Tampilan Sub Menu Data Anggota 
Gambar 16 menunjukkan halaman detail anggota, yang terdiri dari beberapa kolom, di antaranya data surat anggota yang digunakan untuk melihat data surat anggota yang sudah dibuat, data gaji anggota yang digunakan untuk melihat data gaji anggota yang sudah pernah diberikan yang di dapat dari data pengeluaran anggota, data perlengkapan anggota yang digunakan untuk melihat data perlengkapan yang sudah dimiliki oleh anggota serta lampiran anggota yang digunakan untuk melihat kelengkapan pendataan anggota seperti pada gambar.

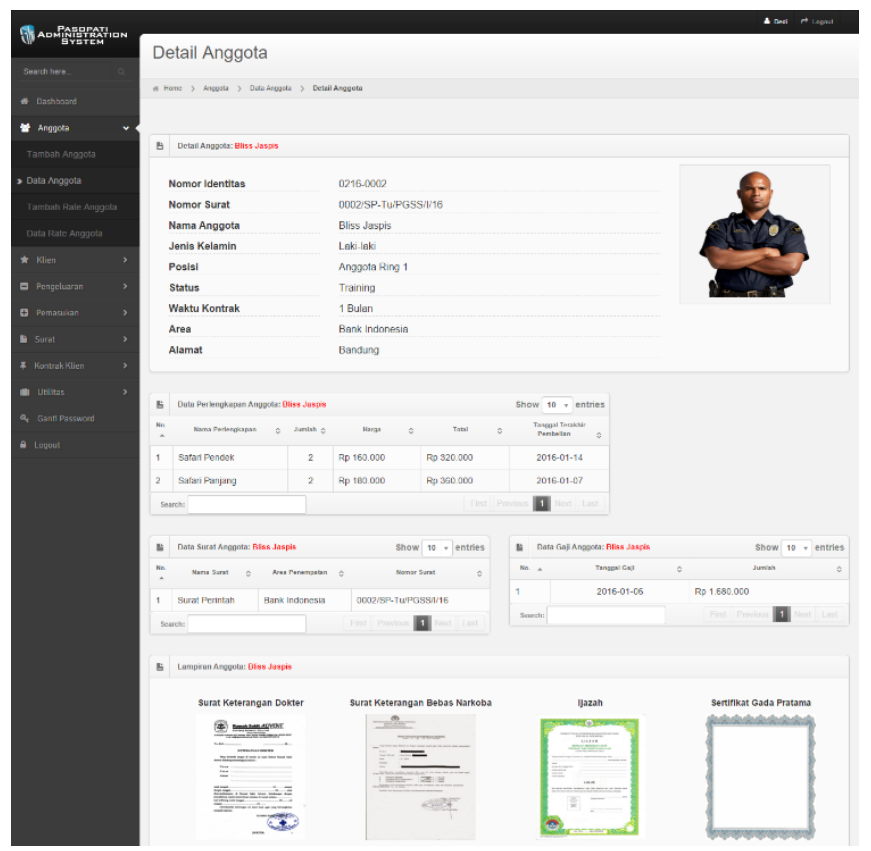

Gambar 16 Tampilan Sub Menu Data Anggota - Detail Anggota

Gambar 17 menunjukkan halaman di mana user akan memasukkan data rate anggota yang akan digunakan pada menu pengeluaran di saat anggota akan menerima gaji.

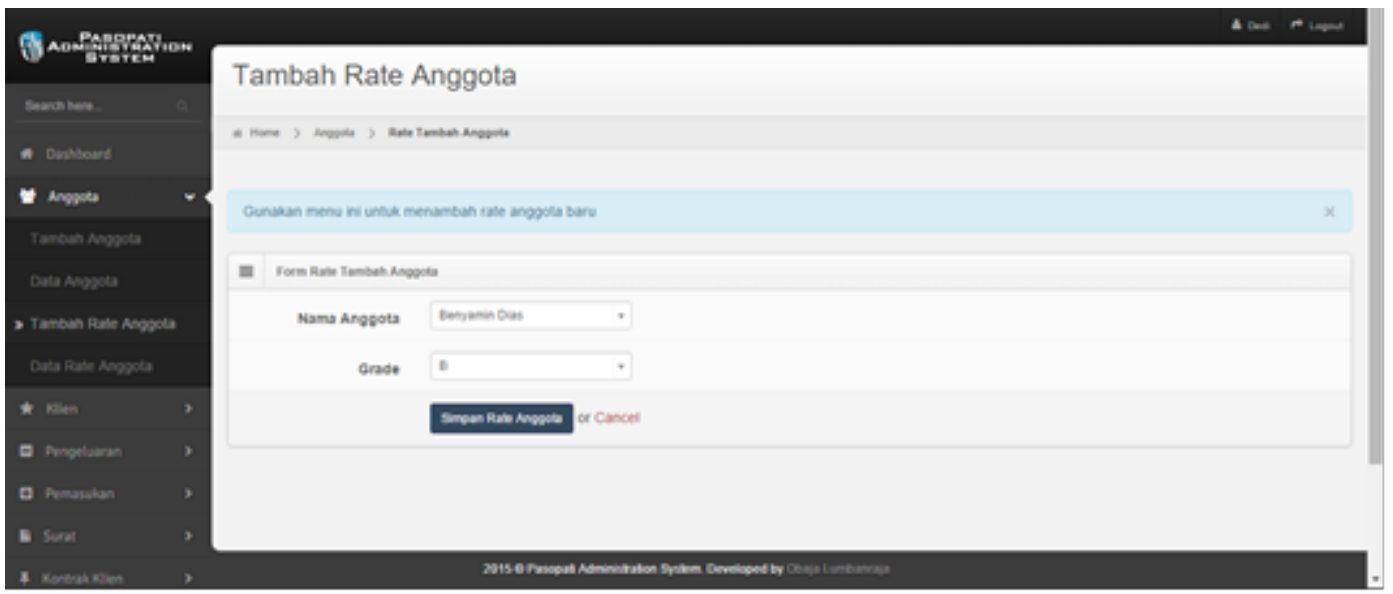

Gambar 17 Tampilan Sub Menu Tambah Rate Anggota

Gambar 18 menunjukkan halaman di mana data yang sudah dimasukkan sebelumnya ditunjukkan beserta nominal dari grade yang dimaksud 


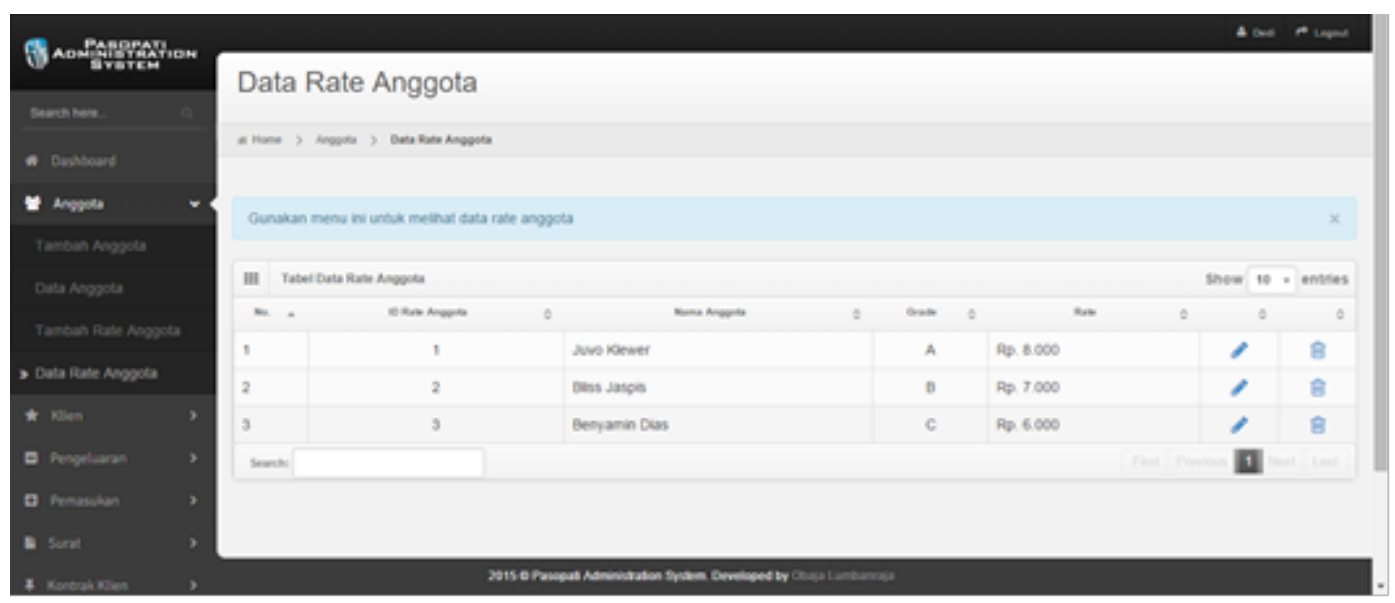

Gambar 18 Tampilan Sub Menu Data Rate Anggota

Menu klien adalah tempat user untuk memasukkan data dan melihat data klien yang sudah dimasukkan sebelumnya dalam bentuk informasi klien yang terdiri dari sub menu klien baru dan data klien yang ditunjukkan pada Gambar 19. Sebelum usermemasukkan data klien maka userharus membuat nomor kontrak di menu kontrak klien terlebih dahulu bila tidak ingin data nomor kontrak ditulis "nomor kontrak belum dibuat".

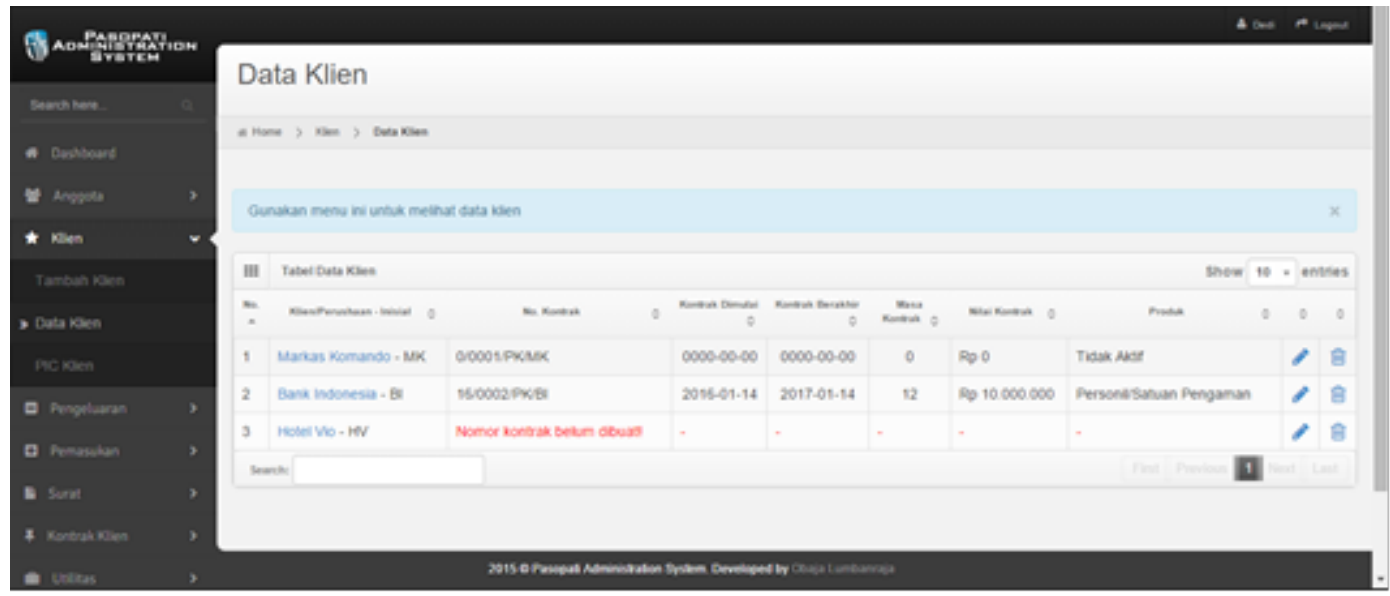

Gambar 19 Tampilan Sub Menu Data Klien

Menu pengeluaran adalah tempat user untuk memasukkan data pengeluaran perlengkapan dan gaji, dan melihat data pengeluaran yang sudah dimasukkan sebelumnya dalam bentuk informasi pengeluaran yang terdiri dari sub menu tambah pengeluaran, data pengeluaran perlengkapan, data pengeluaran gaji yang ditunjukkan pada Gambar 20. 


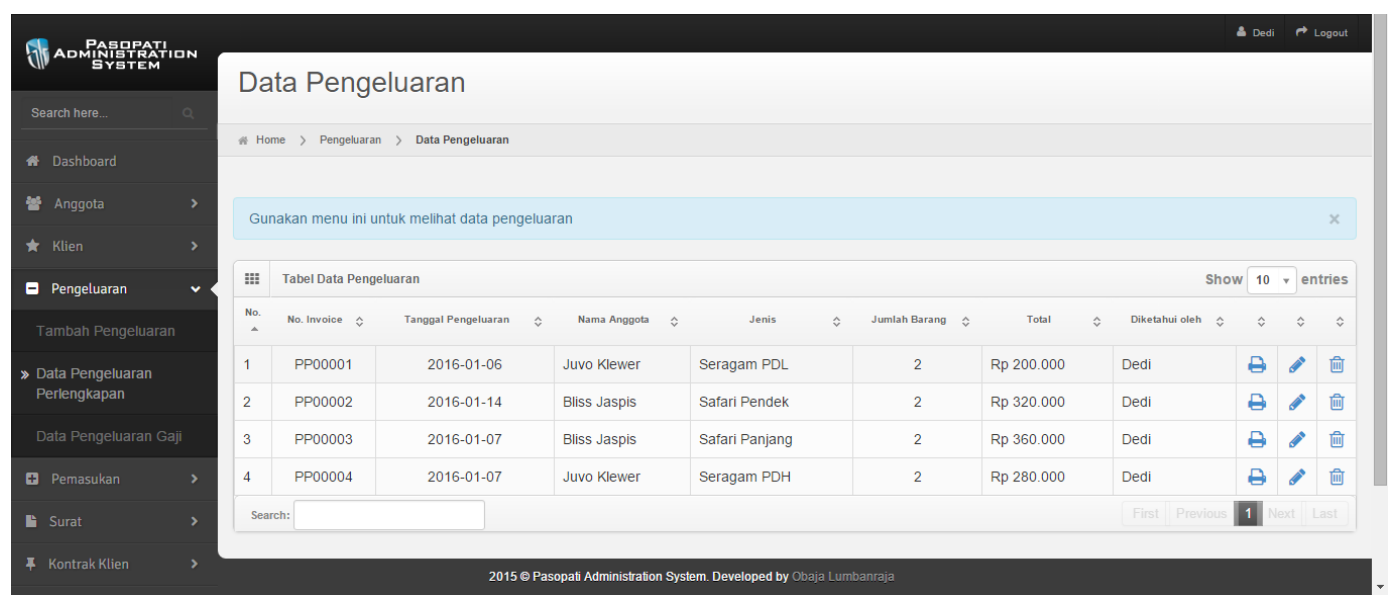

Gambar 20 Tampilan Sub Menu Data Pengeluaran Perlengkapan

Menu pemasukan adalah tempat user untuk memasukkan data dan melihat data pemasukan yang sudah dimasukkan sebelumnya dalam bentuk informasi pemasukan yang terdiri dari sub menu tambah pemasukan dan data pemasukan yang ditunjukkan oleh Gambar 21.

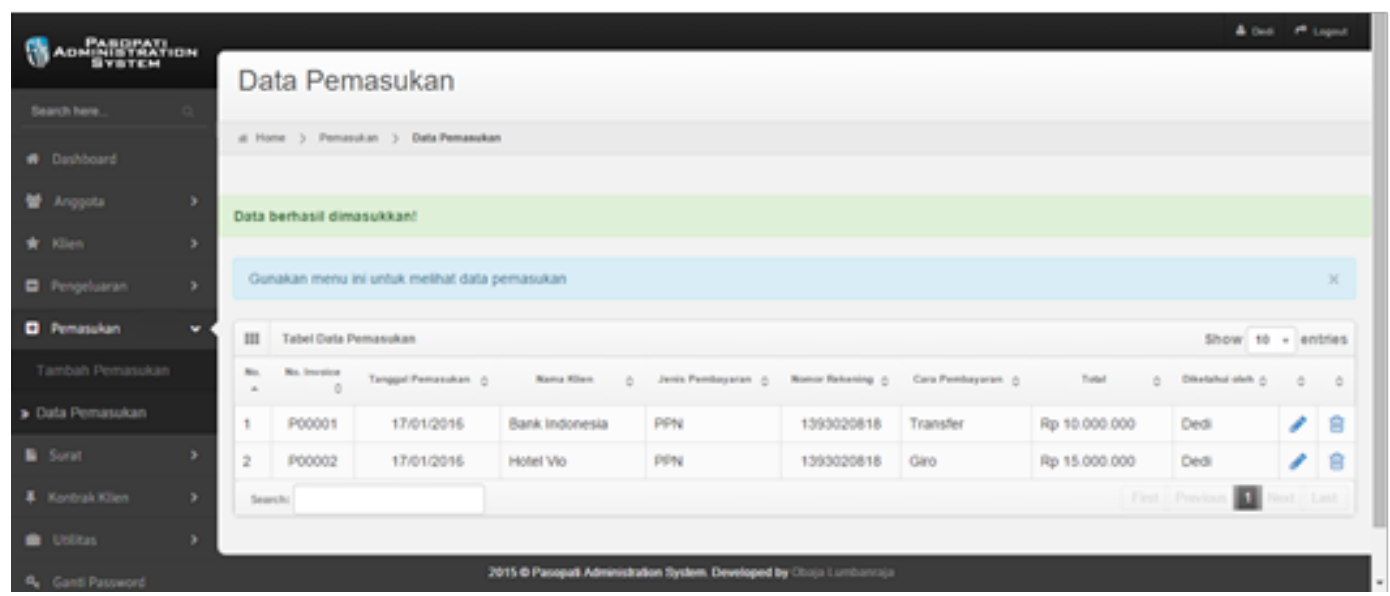

Gambar 20 Tampilan Sub Menu Data Pemasukan

Menu surat adalah tempat user untuk memasukkan data dan melihat data surat yang sudah dimasukkan sebelumnya dalam bentuk informasi surat yang terdiri dari sub menu tambah surat dan data surat yang ditunjukkan pada Gambar 21. 


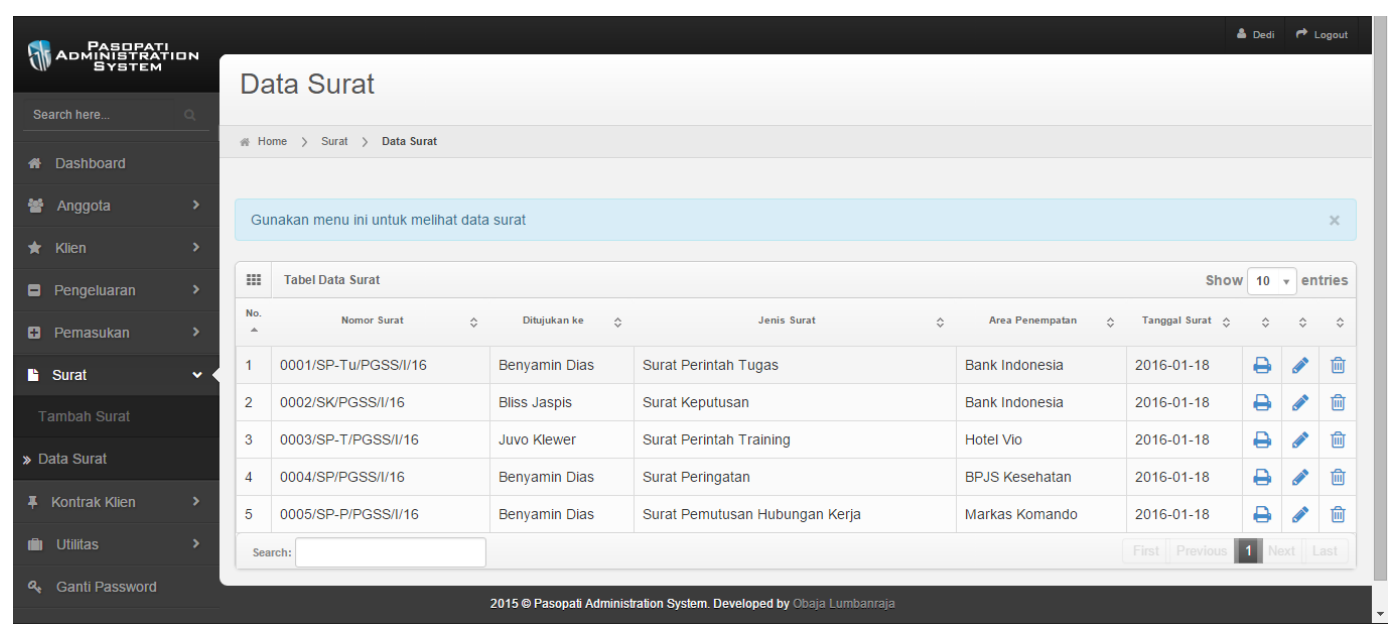

Gambar 21 Tampilan Sub Menu Data Surat

Pada halaman Data Surat, user dapat mencetak surat yang sudah dibuat sebelumnya seperti pada Gambar 22.

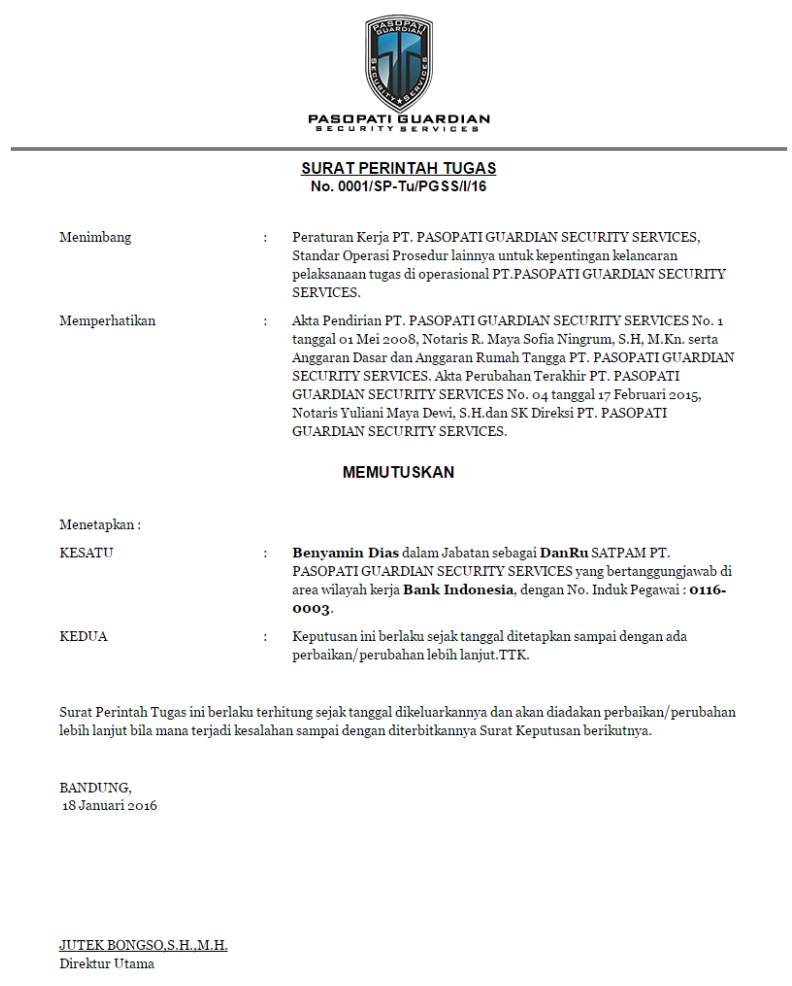

Gambar 22 Tampilan Halaman Print Surat

Menu kontrak klien adalah tempat useruntuk memasukkan data dan melihat data nomor kontrak klien yang sudah dimasukkan sebelumnya dalam bentuk informasi kontrak klien yang terdiri dari sub menu tambah kontrak klien dan data kontrak klien yang ditunjukkan pada Gambar 23. 


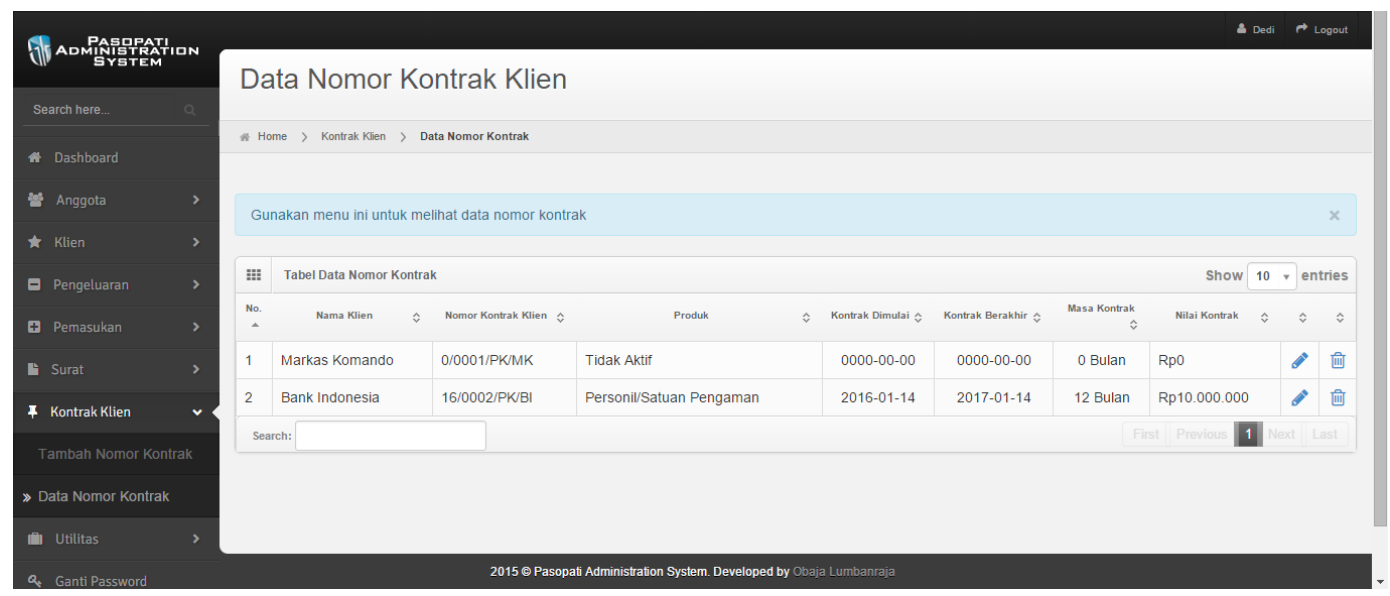

Gambar 23 Tampilan Sub Menu Data Kontrak Baru

Menu utilitas terdiri dari sub menu bank, rate gaji, status, kontrak, produk dan perlengkapan yang berguna untuk melengkapi data pada menu anggota dan klien seperti yang telah dijelaskan sebelumnya. Gambar 24 menunjukkan tampilan halaman bank, pada halaman ini user dapat memasukkan data bank serta melihat data tersebut sesudah dimasukkan.

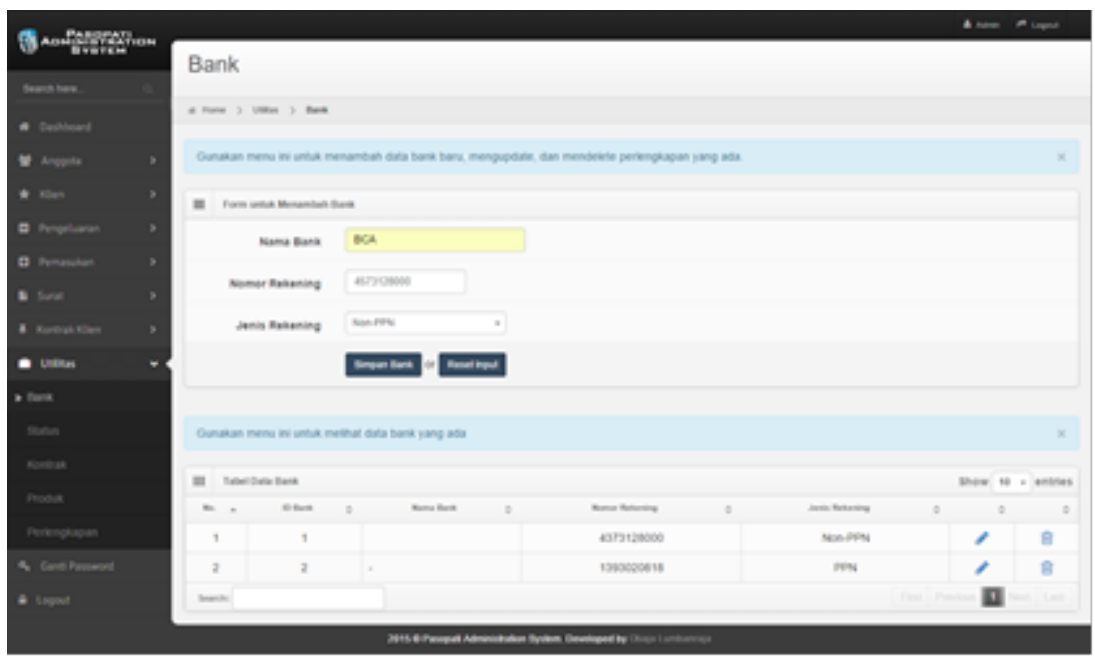

Gambar 24 Tampilan Sub Menu Bank

Menu terakhir pada sistem administrasi ini adalah ganti password. Menu ini digunakan untuk mengubah kata sandi hak akses user yang ditunjukkan pada Gambar 25.

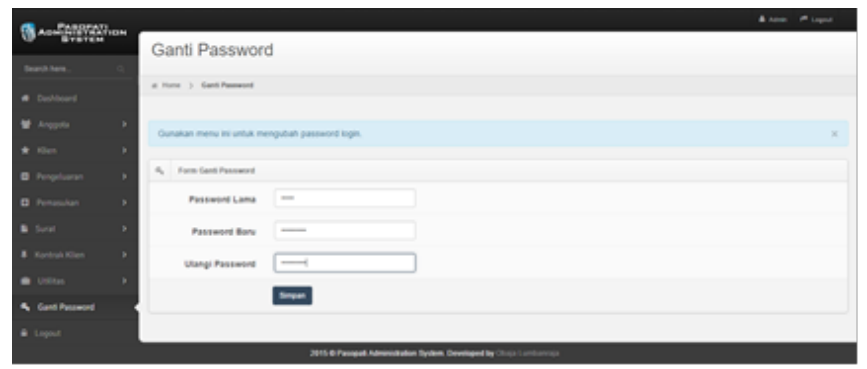

Gambar 25 Tampilan Menu Ganti Password 


\section{Uji Coba Aplikasi}

Pengujian sistem bertujuan untuk melakukan pengecekan terhadap fungsi yang dimiliki oleh sistem apakah sudah berjalan dengan semestinya sesuai dengan harapan pengguna dan dapat berguna bagi pengguna. Adapun metode pengujian yang umum digunakan adalah metode pengujian white box. Pengujian white boxadalah pengujian terhadap suatu program di mana kita dapat melihat dan mengetahui isi/kode dari program tersebut, dalam arti kita mengetahui bagaimana proses terjadinya input dan output dari program tersebut. Pada tabel 2 dapat dilihat hasil dari pengujian sistem administrasi dengan menggunakan metode white box.

Tabel 2 Hasil Pengujian

\begin{tabular}{|c|c|c|c|c|}
\hline No & $\begin{array}{c}\text { Kasus/Form } \\
\text { yang diuji }\end{array}$ & Skenario Uji & Hasil yang diharapkan & $\begin{array}{c}\text { Hasil } \\
\text { Pengujian }\end{array}$ \\
\hline 1 & Landing Page & $\begin{array}{l}\text { Menekan tombol ke } \\
\text { halaman login }\end{array}$ & User diarahkan ke halaman login & Diterima \\
\hline \multirow[b]{2}{*}{2} & \multirow{2}{*}{ Login Sistem } & $\begin{array}{l}\text { Memasukkan data } \\
\text { username dan password } \\
\text { yang benar }\end{array}$ & $\begin{array}{l}\text { Apabila benar maka user akan masuk } \\
\text { ke dalam halam sistem dengan } \\
\text { dashboard sebagai tampilan pertama }\end{array}$ & \multirow{2}{*}{ Diterima } \\
\hline & & $\begin{array}{l}\text { Memasukkan data } \\
\text { username dan password } \\
\text { yang salah }\end{array}$ & $\begin{array}{l}\text { Apabila username dan password salah } \\
\text { user tidak dapat masuk ke dalam } \\
\text { sistem }\end{array}$ & \\
\hline \multirow{4}{*}{3} & \multirow{4}{*}{ Anggota } & $\begin{array}{l}\text { Menambah data baru ke } \\
\text { dalam database }\end{array}$ & $\begin{array}{l}\text { Masukkan data anggota pada form } \\
\text { yang telah disediakan dan tekan } \\
\text { tombol simpan untuk menyimpannya } \\
\text { ke dalam database }\end{array}$ & \multirow{4}{*}{ Diterima } \\
\hline & & Mengubah data & $\begin{array}{l}\text { Mengubah data anggota yang sudah } \\
\text { ada di dalam database }\end{array}$ & \\
\hline & & Menghapus Data & $\begin{array}{l}\text { Menghapus data anggota yang sudah } \\
\text { ada di dalam database }\end{array}$ & \\
\hline & & Melihat Detail Data & $\begin{array}{l}\text { Melihat detail anggota dengan } \\
\text { menekan nama anggota yang } \\
\text { dimaksud }\end{array}$ & \\
\hline \multirow{4}{*}{4} & \multirow{4}{*}{ Klien } & $\begin{array}{l}\text { Menambah data baru ke } \\
\text { dalam database }\end{array}$ & $\begin{array}{l}\text { Masukkan data klien pada form yang } \\
\text { telah disediakan dan tekan tombol } \\
\text { simpan untuk menyimpannya ke } \\
\text { dalam database }\end{array}$ & \multirow{4}{*}{ Diterima } \\
\hline & & Mengubah data & $\begin{array}{l}\text { Mengubah data klien yang sudah ada } \\
\text { di dalam database }\end{array}$ & \\
\hline & & Menghapus Data & $\begin{array}{l}\text { Menghapus data klien yang sudah ada } \\
\text { di dalam database }\end{array}$ & \\
\hline & & Melihat Detail Data & $\begin{array}{l}\text { Melihat detail klien dengan menekan } \\
\text { nama anggota yang dimaksud }\end{array}$ & \\
\hline \multirow{3}{*}{5} & \multirow{3}{*}{ Pengeluaran } & $\begin{array}{l}\text { Menambah data baru ke } \\
\text { dalam database }\end{array}$ & $\begin{array}{l}\text { Masukkan data pengeluaran pada } \\
\text { form yang telah disediakan dan tekan } \\
\text { tombol simpan untuk menyimpannya } \\
\text { ke dalam database }\end{array}$ & \multirow{3}{*}{ Diterima } \\
\hline & & Mengubah data & $\begin{array}{l}\text { Mengubah data pengeluaran yang } \\
\text { sudah ada di dalam database }\end{array}$ & \\
\hline & & Menghapus Data & $\begin{array}{l}\text { Menghapus data pengeluaran yang } \\
\text { sudah ada di dalam database }\end{array}$ & \\
\hline \multirow[t]{2}{*}{6} & \multirow[t]{2}{*}{ Pemasukan } & $\begin{array}{l}\text { Menambah data baru ke } \\
\text { dalam database }\end{array}$ & $\begin{array}{l}\text { Masukkan data pemasukan pada form } \\
\text { yang telah disediakan dan tekan } \\
\text { tombol simpan untuk menyimpannya } \\
\text { ke dalam database }\end{array}$ & \multirow[t]{2}{*}{ Diterima } \\
\hline & & Mengubah data & $\begin{array}{l}\text { Mengubah data pemasukan yang } \\
\text { sudah ada di dalam database }\end{array}$ & \\
\hline
\end{tabular}




\begin{tabular}{|c|c|c|c|c|}
\hline No & $\begin{array}{c}\text { Kasus/Form } \\
\text { yang diuji }\end{array}$ & Skenario Uji & Hasil yang diharapkan & $\begin{array}{c}\text { Hasil } \\
\text { Pengujian }\end{array}$ \\
\hline & & Menghapus Data & $\begin{array}{l}\text { Menghapus data pemasukan yang } \\
\text { sudah ada di dalam database }\end{array}$ & \\
\hline \multirow{3}{*}{7} & \multirow{3}{*}{ Surat } & $\begin{array}{l}\text { Menambah data baru ke } \\
\text { dalam database }\end{array}$ & $\begin{array}{l}\text { Masukkan data surat pada form yang } \\
\text { telah disediakan dan tekan tombol } \\
\text { simpan untuk menyimpannya ke } \\
\text { dalam database }\end{array}$ & \multirow{3}{*}{ Diterima } \\
\hline & & Mengubah data & $\begin{array}{l}\text { Mengubah data surat yang sudah ada } \\
\text { di dalam database }\end{array}$ & \\
\hline & & Menghapus Data & $\begin{array}{l}\text { Menghapus data surat yang sudah } \\
\text { ada di dalam database }\end{array}$ & \\
\hline \multirow{3}{*}{8} & \multirow{3}{*}{ Kontrak Klien } & $\begin{array}{l}\text { Menambah data baru ke } \\
\text { dalam database }\end{array}$ & $\begin{array}{l}\text { Masukkan data kontrak klien pada } \\
\text { form yang telah disediakan dan tekan } \\
\text { tombol simpan untuk menyimpannya } \\
\text { ke dalam database }\end{array}$ & \multirow{3}{*}{ Diterima } \\
\hline & & Mengubah data & $\begin{array}{l}\text { Mengubah data kontrak klien yang } \\
\text { sudah ada di dalam database }\end{array}$ & \\
\hline & & Menghapus Data & $\begin{array}{l}\text { Menghapus data kontrak klien yang } \\
\text { sudah ada di dalam database }\end{array}$ & \\
\hline \multirow{3}{*}{9} & \multirow{3}{*}{ Utilitas } & $\begin{array}{l}\text { Menambah data baru ke } \\
\text { dalam database }\end{array}$ & $\begin{array}{l}\text { Masukkan data utilitas pada form } \\
\text { yang telah disediakan dan tekan } \\
\text { tombol simpan untuk menyimpannya } \\
\text { ke dalam database }\end{array}$ & \multirow{3}{*}{ Diterima } \\
\hline & & Mengubah data & $\begin{array}{l}\text { Mengubah data utilitas yang sudah } \\
\text { ada di dalam database }\end{array}$ & \\
\hline & & Menghapus Data & $\begin{array}{l}\text { Menghapus data utilitas yang sudah } \\
\text { ada di dalam database }\end{array}$ & \\
\hline \multirow{3}{*}{10} & \multirow{3}{*}{ Ganti Password } & $\begin{array}{l}\text { Informasi Kesalahan } \\
\text { Password Lama }\end{array}$ & $\begin{array}{l}\text { Tampil informasi kesalahan input } \\
\text { password lama }\end{array}$ & \multirow{3}{*}{ Diterima } \\
\hline & & $\begin{array}{l}\text { Informasi Kesalahan } \\
\text { Password Baru }\end{array}$ & $\begin{array}{l}\text { Tampil informasi kesalahan input } \\
\text { password baru }\end{array}$ & \\
\hline & & Tombol Ganti Password & Kembali ke halaman login bila berhasil & \\
\hline 11 & Logout & Tombol Keluar Sistem & Kembali ke halaman login bila berhasil & Diterima \\
\hline
\end{tabular}

\section{Pembahasan/Kesimpulan}

Berdasarkan hasil dari perancangan sistem informasi administrasi jasa keamanan beserta hasilnya maka penulis menyimpulkan bahwa: 1 . Sistem yang dibangun dapat meningkatkan kinerja karyawan dalam melakukan pekerjaannya; 2 . Sistem yang dibangun dapat menyimpan dan menampilkan data pengeluaran keuangan dan pemasukan sesuai dengan data yang sebenarnya sehingga data lama dan baru dapat di analisa dengan baik; 3 . Sistem yang dibangun dapat mengintegrasikan data antara anggota satuan pengaman dengan klien dengan benar sehingga dapat diketahui jumlah anggota yang ada di lokasi klien; 4. Sistem yang dibangun dapat membantu pengguna untuk membuat faktur sebelum tanggal jatuh tempo pembayaran oleh klien dan mengurangi kerugian yang dapat terjadi.

Adapun saran yang dapat di berikan oleh penulis untuk penggunaan serta peningkatan sistem agar menjadi lebih baik adalah sebagai berikut: 1 . Karena perancangan sistem administrasi ini menggunakan HTML5, maka user disarankan untuk menggunakan browser Chrome untuk mengakses sistem administrasi ini guna mendapatkan hasil yang lebih baik dalam tampilan maupun menu-menu yang terdapat di dalamnya. 2. Untuk meningkatkan keamanan dari data yang ada, maka penulis menyarankan perusahaan untuk mengaplikasikan sistem ini secara lokal saja atau intranet, yang artinya hanya dapat diakses di dalam area perusahaan. 


\section{Daftar Pustaka}

[1] Stair, R., dan Reynolds, G., Principles of Information Systems 9 Ed. USA: Cengage Learning, 2010, pp. 4-10.

[2] Rainer Jr, R. K., dan Cegielski, C. G., Introduction to Information Systems 3Ed. USA: John Wiley \& Sons, Inc., 2011, pp. 7-11.

[3] Haryadi, H., Administrasi Perkantoran untuk Manajer dan Staff. Indonesia: Visimedia, 2009, pp. 1-3.

[4] Kristanto, A., Perancangan Sistem Informasi dan Aplikasinya. Yogyakarta: Gaya Media, 2008 pp. 61.

[5] Coronel, C., Morris, S., et. al, Database Systems Design, Implementation and Management 9th. Ed.. USA: Cengage Learning, 2011, pp. 7\&100.

[6] Teorey, T., Lightstone, S., et. al, Database Modeling and Design Logical Design 5th. Ed.. USA: Elsevier Inc., 2011, pp. 15-18.

[7] Davis, M. E., dan Phillips, J. A., Learning PHP and MySQL, Second Edition. USA: O'Reilly Media, Inc., 2007, pp. 4-6.

[8] Mendez, C. A., Villa, C., et. Al, Learning Ext JS, Fourth Edition. UK: Packt Publishing, 2015, pp. 15.

[9] Duckett, J., HTML \& CSS Design and Build Websites. USA: John Wiley \& Sons, Inc., 2011, pp. 20, 22 \& 25.

[10] Larsen, R., Beginning HTML \& CSS. USA: John Wiley \& Sons, Inc., 2013, pp. 192. 